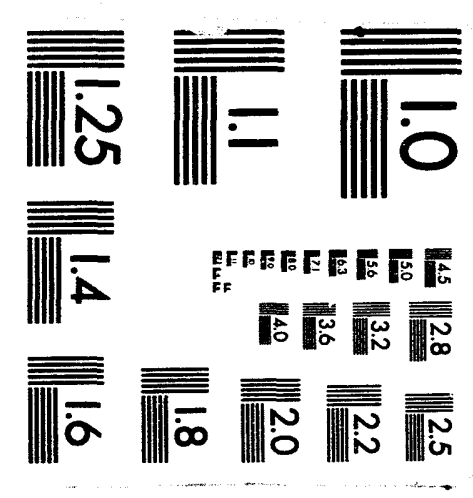



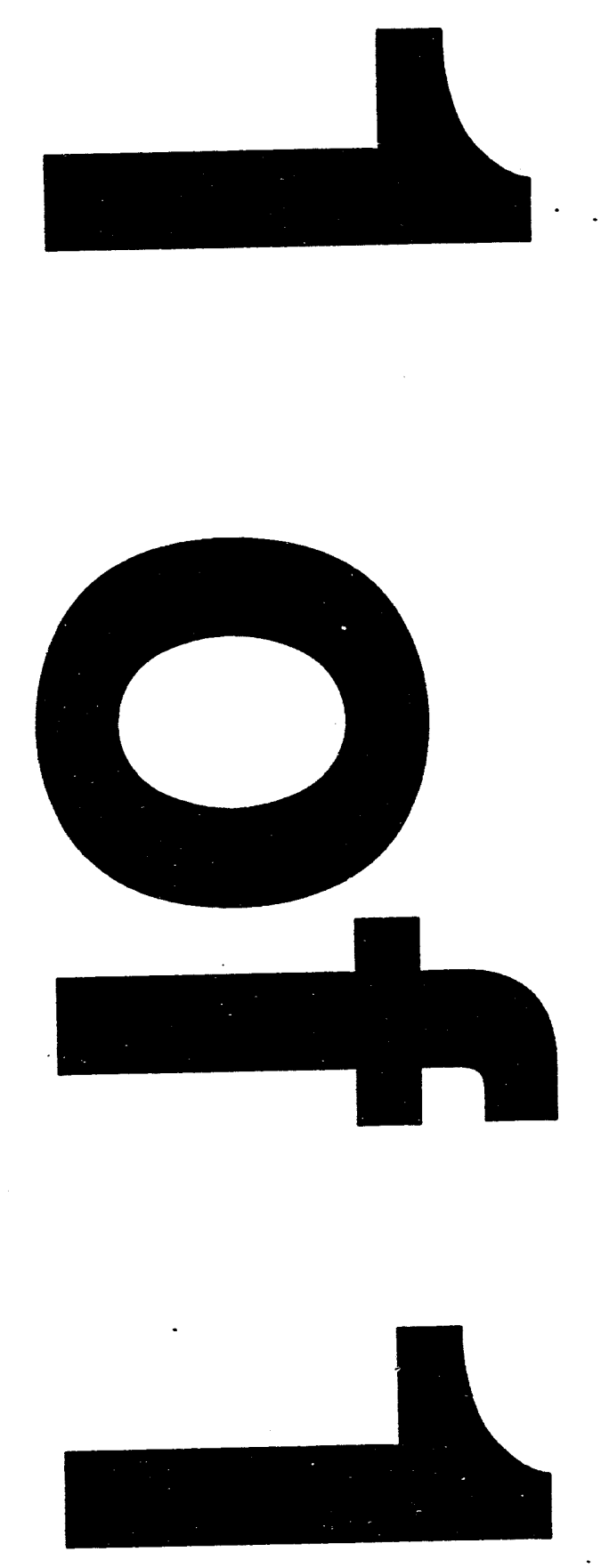


\section{The Comparative Impact of the Market Penetration of Energy-Efficient Measures. A Sensitivity Analysis of Its Impact on Minority Households}

by L.V. Bozinovich, D.A. Poyer, and J.L. Anderson

Energy Systems Division,

Argonne National Laboratory, 9700 South Cass Avenue, Argonne, Illinois 60439

Work sponsored by United States Department of Energy,

Office of Economic Impact and Diversity 


\section{CONTENTS}

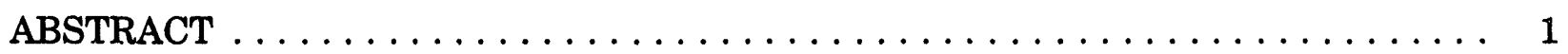

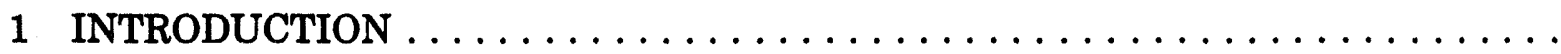

2 METHODOLOGY AND REPORTING PROTOCOL $\ldots \ldots \ldots \ldots \ldots \ldots \ldots$

3 RESULTS FROM THE STATUS QUO SCENARIO, 5\% NEW HOUSING GROWTH $\ldots \ldots \ldots \ldots \ldots \ldots \ldots \ldots \ldots \ldots \ldots \ldots \ldots$

4 RESULTS FROM THE $4 \%$ NEW HOUSING GROWTH SCENARIO $\ldots \ldots \ldots \ldots 17$

5 RESULTS FROM THE 6\% NEW HOUSING GROWTH SCENARIO . . . . . . 25

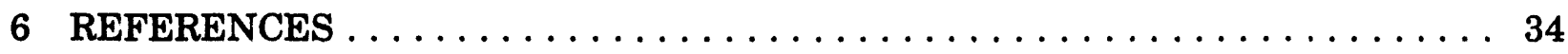

\section{TABLES}

1 Total Energy and Electricity Consumption and Expenditures, Status Quo Scenario, Reference Case, $5 \%$ New Housing Growth $\ldots \ldots \ldots \ldots \ldots$

2 Total Energy Consumption and Expenditures, Status Quo

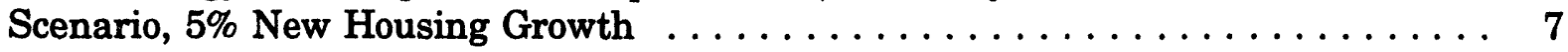

3 Electricity Consumption and Expenditures, Status Quo Scenario, 5\% New Housing Growth

4 Total Energy Consumption and Expenditures, Minus the Reference Case, Status Quo Scenario, 5\% New Housing Growth ......... 10

5 Electricity Consumption and Expenditures, Minus the Reference Case, Status Quo Scenario, 5\% New Housing Growth $\ldots \ldots \ldots \ldots 12$

6 Total Energy Consumption Trends, Status Quo Scenario, $5 \%$ New Housing Growth $\ldots \ldots \ldots \ldots \ldots \ldots \ldots \ldots \ldots \ldots \ldots \ldots \ldots$

7 Electricity Consumption Trends, Status Quo Scenario, 5\% New

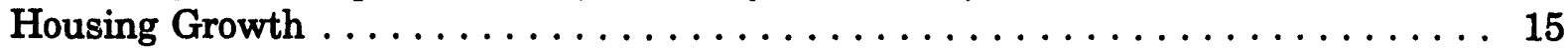

8 Total Energy Consumption and Expenditures, NES4 Scenario, $4 \%$ New Housing Growth $\ldots \ldots \ldots \ldots \ldots \ldots \ldots \ldots \ldots \ldots \ldots \ldots \ldots \ldots$

9 Electricity Consumption and Expenditures, NES4 Scenario, 4\% New Housing Growth 


\section{TABLES (Cont.)}

10 Total Energy Consumption and Expenditures, Minus the Reference Case, NES4 Scenario, $4 \%$ New Housing Growth $\ldots \ldots \ldots \ldots \ldots \ldots 21$

11 Electricity Consumption and Expenditures, Minus the Reference Case, NES4 Scenario, $4 \%$ New Housing Growth $\ldots \ldots \ldots \ldots \ldots \ldots 22$

12 Total Energy Consumption Trends, NES4 Scenario, 4\% New Housing

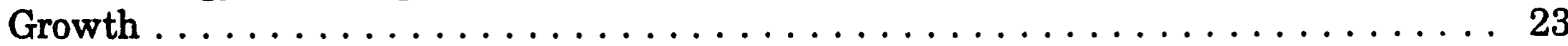

13 Electricity Consumption Trends, NES4 Scenario, 4\% New Housing Growth . . . 24

14 Total Energy Consumption and Expenditures, NES6 Scenario,

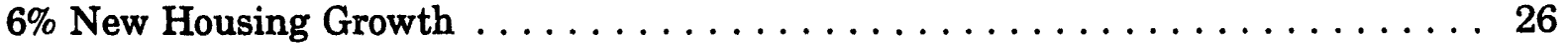

15 Electricity Consumption and Expenditures, NES6 Scenario, 6\% New

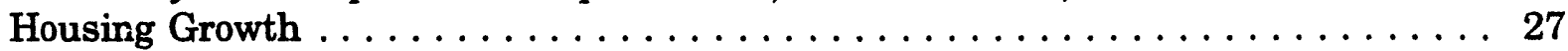

16 Total Energy Consumption and Expenditures, Minus the Reference Case, NES6 Scenario, 6\% New Housing Growth

17 Electricity Consumption and Expenditures, Minus the Reference Case, NES6 Scenario, 6\% New Housing Growth . . . . . . . . . . . 30

18 Total Energy Consumption Trends, NES6 Scenario, 6\% New

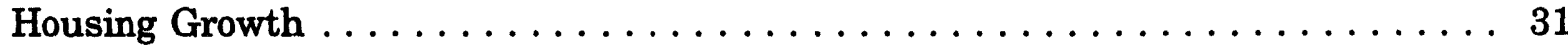

19 Electricity Consumption Trends, NES6 Scenario, 6\% New Housing

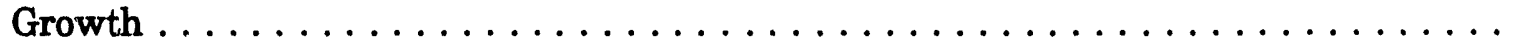

20 Relative Rankings of Minority Groups in Each ESR Market Penetration Case and in Each Housing Growth Scenario 


\title{
THE COMPARATIVE IMPACT OF THE MARKET PENETRATION OF ENERGY-EFFICIENT MEASURES: A SENSITIVITY ANALYSIS OF ITS IMPACT ON MINORITY HOUSEHOLDS
}

by

\author{
L.V. Bozinovich, D.A. Poyer, and J.L. Anderson
}

\begin{abstract}
A sensitivity study was made of the potential market penetration of residential energy efficiency as energy service ratio (ESR) improvements occurred in minority households, by age of house. The study followed a Minority Energy Assessment Model analysis of the National Energy Strategy projections of household energy consumption and prices, with majority, black, and Hispanic subgroup divisions. Electricity and total energy consumption and expenditure patterns were evaluated when the households' ESR improvement followed a logistic negative growth (i.e., market penetration) path. Earlier occurrence of ESR improvements meant greater discounted savings over the 22-year period.
\end{abstract}

\section{INTRODUCTION}

In our sensitivity analysis of the impacts of market penetration of energy-efficient measures on minority households, the effects of varying the energy service ratio (ESR) were examined in two different ways. The ESR designates the efficiency of fuel use in a home; under the reference case, it declines at a constant rate over time. An ESR value of one denotes that the units of fuel used for each unit of energy service received are in a one-to-one relationship. A household's reference-case base-period energy consumption is used to normalize its ESR to one. An ESR value of 0.9 denotes that 0.9 units of fuel are necessary for each unit of energy service consumed.

When the ESR is set up to be a function of time, it represents the market penetration of energy-efficiency measures into the home. As energy-efficiency measures are implemented gradually over time, a home will show a corresponding drop in its ESR. As more efficiency measures are implemented, the ESR will drop further still. Its path will be a curved line over time, which is indicative of logistic negative growth.

We postulated that two ESR curves can be used to study the sensitivity of energy use. The New House ESR curve declines rapidly in the beginning and then levels off as we approach the last year of our forecast. The Old House ESR curve declines gradually at first; after some period, it starts a more rapid decline and then levels off toward the very end of 
the forecast period. Residential structures built after 1974 are designated as new; those built on or before 1974 are designated as old.

The New House ESR curve is applicable when stronger energy-saving measures are taken in the early years. The cumulative effect of these measures over 22 years results in an ESR of 0.9155, which occurs within a few years of the last period of the study. We postulate that this pattern resembles the behavior in a new house. A new house is more thermally efficient, and its ESR will be better than one at the beginning because the reference case ESR is one in the first period. Additionally, measures implemented in a new house are less likely to cost as much or take as much time to install as they would in an old house (less retrofitting, etc.). Therefore, any significant energy-saving measures would more likely be implemented early.

The Old House ESR curve is applicable when the strongest energy-saving measures are postponed and few effective measures are taken initially. A cumulative effect occurs as measures are implemented over time. The addition of delayed significant measures results in the final year's ESR reaching the value of 0.9155 , as it does for the New House ESR curve and the reference case. We postulate that this behavior more closely resembles that which would take place in an old house, where retrofitting may be necessary to thermally insulate windows, the furnace may require overhauling or replacement, and the minor efficiency measures that are implemented in earlier years provide a negligible effect in lowering the ESR.

The ESR curves are not intended to directly reflect the ability of the homeowners to afford home improvements, because we assume that homeowners will postpone costly purchases. As the NES (1991) explains, prior experiences have shown that households tend to underinvest in energy-efficiency improvements. ${ }^{1}$ The income differences among homeowners are captured in the household energy and electricity usage behavior, the end-use appliance composition, and, to some extent, the age of the house.

The ESR curve does bear some relation to household income and welfare, through its effect on household energy consumption and expenditures. A New House ESR curve will provide more favorable effects than will an Old House ESR curve. Owing to the differential distributions of subgroup members among old and new homes, and to the rates and directions of change of the subgroup distributions over time, some population subgroups will be more sensitive to the market penetration of energy efficiency than will others.

1 Other studies corroborate this assertion; see Bozinovich and Ungson (1991) for an overview. 


\section{METHODOLOGY AND REPORTING PROTOCOL}

The population subgroups we studied (majority, black, and Hispanic) each had a different mix of New House and Old House residents, which is characteristic of the groups at large. The three scenarios we looked at each had a different rate of new housing growth. The housing growth rate in the status quo scenario is 5\%, that in the NES4 scenario is $4 \%$, and that in the NES6 scenario is $6 \%$. We looked at the sensitivity of each subgroup's energy use, through time, to the postulated change in the ESR. We first examined the sensitivity to the ESR across groups within a housing growth scenario, and then the sensitivity to the ESR across scenarios. We looked at both electric energy usage and total energy usage.

Our two cases are (1) the New House/Old House (N/O) case, reflective of real and projected subgroup residency conditions, in which the portion of a subgroup residing in new housing and that in old housing are assigned the appropriate ESR curve and the reported result is a composite of the differential effects the two curves have on each subgroup; and (2) the New House (N) case, representing the contrasting ideal case, in which both portions of a subgroup are treated as if they reside in a new house and their behavior is reflective of their sensitivity to the New House ESR curve. These two cases are compared to the reference case.

Given the complete demand data available to the Minority Energy Assessment Model (MEAM), our energy demand modeling was done at the microdata level; the usage behavior in each household was modeled as if the household maximized its utility, subject to prices, the ESR, and household income. The concept of representative agent, drawn from the utility maximization theory in economics, implies that one may model the energy use of a whole subgroup as if there were a representative agent making decisions for that subgroup. The concept of representative agent used here is intended to apply only to the average outcome amounts, which are the predicted levels of energy usage by the average household within a subgroup. Although the outcomes are viewed as representative of a typical member of the respective subgroup, the inputs are based on individual household choices. Therefore, any variance among individuals is captured before the averaging is done.

The energy expenditure for the full reporting period was discounted at $5 \%$ (continuously compounded) to represent the time value of money expenditure. The welfare impact of an equivalent face-value saving, delayed in time, is less positive than one in which all savings occur in the first period. The tables display undiscounted savings on the biennial line items, while the table sums for expenditure are discounted and those for consumption are not. Subgroup households may place a value on having consumption utility now rather than later, and this can be represented by the subgroup household's rate of time preference. Like a discount rate, this value permits us to understand how consumption choices are made over time. We do not consider discounted consumption utility in this report.

Biennial reporting of annual amounts provides us with the scope of behavioral changes occurring over 22 years. This period encompasses demographic shifts due to varying 
rates of population growth and energy price changes predicted by the National Energy Strategy (NES).

The time path of each ESR curve varies, and, for that reason, greater savings have been measured up front for people residing in new homes than for those residing in old homes. The discounting will implicitly weigh the up-front savings more and the delayed savings less and will predict, all else being equal, greater early-occurring welfare gains and smaller late-occurring welfare losses for those subgroups whose members live in newer homes. Therefore, it is the discounted expenditure amounts that we address in this report. Consumption is addressed in undiscounted form. 


\section{RESULTS FROM THE STATUS QUO SCENARIO, • 5\% NEW HOUSING GROWTH}

In the reference case, the status quo scenario, total energy ${ }^{2}$ consumption and expenditure amounts were found to vary among population subgroups (see Table 1). We found that the relative ranking among subgroups, from high to low energy use, was preserved in the two new cases, but the magnitude of relative differences across subgroups was not. In the N/O case, the average household of the black subgroup consumed the most energy of all the subgroups at $1,285 \times 10^{6}$ Btu over 12 years, reported within the 22-year period (19872009) (see Table 2). The agent from the majority subgroup consumed the next highest amount of total energy at $1,139 \times 10^{6} \mathrm{Btu}$ for the period, and the Hispanic subgroup consumed the least total energy at $1,028 \times 10^{6} \mathrm{Btu}$ for the period. Under the $\mathrm{N}$ case, the total energy consumption declines for all groups, with the black subgroup consuming $1,144 \times 10^{6} \mathrm{Btu}$, the majority subgroup consuming $1,113 \times 10^{6} \mathrm{Btu}$, and the Hispanic agent consuming $998 \times 10^{6} \mathrm{Btu}$.

Comparing energy consumption between the $\mathrm{N} / \mathrm{O}$ case and the $\mathrm{N}$ case indicates how far the real conditions are from the ideal for a particular subgroup. We found that the relative difference in total energy consumption between the $N / O$ case and the $N$ case was 2.3\% greater for members within the majority subgroup, 3.3\% greater for those within the black subgroup, and $3.0 \%$ greater for the Hisfanic subgroup. These numbers showed that the black subgroup was farther from its ideal consumption of total energy than were the two other groups. The relative difference in total energy expenditure was $2.1 \%$ greater within the majority subgroup, $3.15 \%$ greater within the black subgroup, and $2.8 \%$ greater within the Hispanic subgroup. The typical black subgroup member was farthest from its ideal in total energy expenditure. The typical Hispanic subgroup member was about 0.4 percentage points ahead of the black subgroup member and 0.6 percentage points behind the typical majority subgroup member. The majority subgroup member was nearest its ideal in both consumption and expenditure.

Electricity consumption rankings (see Table 3) differed from those for total energy consumption. The largest consumer of electric energy in the $\mathrm{N} / \mathrm{O}$ case was the majority agent, at $416 \times 10^{6} \mathrm{Btu}$ for 12 years during the 22 -year period. The next highest consumer was the black agent, at $346 \times 10^{6} \mathrm{Btu}$; the lowest electricity consumer was the Hispanic agent, at $323 \times 10^{6} \mathrm{Btu}$. In the $\mathrm{N}$ case, the consumption rankings retained the $\mathrm{N} / \mathrm{O}$ and the reference case order for electricity consumption. The majority agent consumed $410 \times 10^{6} \mathrm{Btu}$ of electricity in the $\mathrm{N}$ case, the black agent consumed $337 \times 10^{6} \mathrm{Btu}$, and the Hispanic agent consumed $315 \times 10^{6} \mathrm{Btu}$.

2 "Total energy" is all the residential energy (i.e., electricity, gas, fuel oil, etc. accounted for in units of $10^{6} \mathrm{Btu}$ ) used by a typical household, and not the total of all households' energy use. 
TABLE 1 Total Energy and Electricity Consumption and Expenditures, Status Quo Scenario, Reference Case, 5\% New Housing Growth

\begin{tabular}{|c|c|c|c|c|c|c|c|c|c|c|c|c|}
\hline \multirow[b]{3}{*}{ Year } & \multicolumn{6}{|c|}{$\begin{array}{l}\text { Energy ESR Decline at Constant Rate of }-0.04 \\
\text { Applied Evenly to All Groups, Reference Case }\end{array}$} & \multicolumn{6}{|c|}{$\begin{array}{l}\text { Electricity ESR Decline at Constant Rate of }-0.04 \\
\text { Applied Evenly to All Groups, Reference Case }\end{array}$} \\
\hline & \multicolumn{2}{|c|}{ Majority } & \multicolumn{2}{|c|}{ Black } & \multicolumn{2}{|c|}{ Hispanic } & \multicolumn{2}{|c|}{ Majority } & \multicolumn{2}{|c|}{ Black } & \multicolumn{2}{|c|}{ Hispanic } \\
\hline & $\begin{array}{c}\text { Consump- } \\
\text { tion }^{\mathbf{a}}\end{array}$ & $\begin{array}{c}\text { Expendi- } \\
\text { ture }^{b}\end{array}$ & $\begin{array}{c}\text { Consump- } \\
\text { tion }\end{array}$ & $\begin{array}{l}\text { Expendi- } \\
\text { ture }\end{array}$ & $\begin{array}{l}\text { Consump- } \\
\text { tion }\end{array}$ & $\begin{array}{c}\text { Expendi- } \\
\text { ture }\end{array}$ & $\begin{array}{l}\text { Consump- } \\
\text { tion }\end{array}$ & $\begin{array}{c}\text { Expendi- } \\
\text { ture }\end{array}$ & $\begin{array}{l}\text { Consump- } \\
\text { tion }\end{array}$ & $\begin{array}{l}\text { Expendi- } \\
\text { ture }\end{array}$ & $\begin{array}{l}\text { Consump- } \\
\text { tion }\end{array}$ & $\begin{array}{l}\text { Expendi- } \\
\text { ture }\end{array}$ \\
\hline 1987 & 99.9 & $1,269.4$ & 110.3 & $1,354.9$ & 86.8 & $1,189.8$ & 31.5 & 758.5 & 27.3 & 696.0 & 26.1 & 705.8 \\
\hline 1989 & 102.8 & $1,177.7$ & 112.4 & $1,249.6$ & 90.4 & $1,090.4$ & 33.0 & 710.0 & 28.4 & 647.0 & 26.4 & 641.2 \\
\hline 1991 & 100.9 & $1,197.3$ & 111.2 & $1,295.6$ & 86.5 & $1,094.9$ & 33.4 & 706.0 & 29.2 & 654.9 & 26.9 & 641.1 \\
\hline 1993 & 99.4 & $1,294.0$ & 110.7 & $1,294.6$ & 87.6 & $1,125.0$ & 34.1 & 725.7 & 28.8 & 650.9 & 27.0 & 648.9 \\
\hline $\begin{array}{l}1995 \\
1997\end{array}$ & 97.6 & $1,251.3$ & 107.9 & $1,331.2$ & 86.6 & $1,167.6$ & 34.0 & 769.5 & 28.8 & 689.2 & 27.5 & 694.6 \\
\hline $\begin{array}{l}1997 \\
1999\end{array}$ & 94.8 & $1,384.4$ & 105.2 & $1,477.0$ & 83.6 & $1,277.7$ & 34.6 & 857.5 & 28.8 & 759.1 & 26.0 & 731.5 \\
\hline $\begin{array}{l}1999 \\
2001\end{array}$ & 92.9 & $1,519.0$ & 104.4 & $1,674.9$ & 84.4 & $1,449.8$ & 35.7 & 905.4 & 30.1 & 815.4 & 27.1 & 781.6 \\
\hline $\begin{array}{l}2001 \\
2003\end{array}$ & 91.6 & $1,408.0$ & 103.6 & $1,528.8$ & 83.6 & $1,332.2$ & 35.5 & 887.4 & 28.6 & 761.9 & 27.3 & 763.5 \\
\hline $\begin{array}{l}2003 \\
2005\end{array}$ & 90.5 & $1,268.4$ & 101.9 & $1,325.9$ & 82.0 & $1,179.3$ & 34.6 & 843.8 & 27.2 & 708.1 & 26.1 & 726.0 \\
\hline $\begin{array}{l}2005 \\
2007\end{array}$ & 89.2 & $1,253.4$ & 102.6 & $1,328.3$ & 82.7 & $1,167.9$ & 35.5 & 840.7 & 27.5 & 699.1 & 26.0 & 699.3 \\
\hline $\begin{array}{l}2007 \\
2009\end{array}$ & $\begin{array}{l}87.7 \\
84.8\end{array}$ & $1,295.3$ & 99.8 & $1,388.8$ & 81.9 & $1,223.5$ & 36.5 & 839.2 & 28.4 & 696.1 & 26.5 & 693.1 \\
\hline $\mathrm{T}$ & 84.8 & $1,362.1$ & 97.2 & $1,505.6$ & 79.5 & $1,295.9$ & $37 . \dot{0}$ & 869.4 & 29.2 & 721.5 & 27.1 & 712.2 \\
\hline $\begin{array}{l}\text { Total Con- } \\
\text { sumption }\end{array}$ & 1,132 & & 1,267 & & 1,016 & & 416 & & 342 & & 320 & \\
\hline Discounted & & 11,950 & & 12,835 & & 11,175 & & 7,403 & & 6,520 & & 6,474 \\
\hline
\end{tabular}

a $10^{6} \mathrm{Btu} / \mathrm{yr}$ per household.

b \$/yr per household. 
TABLE 2 Total Energy Consumption and Expenditures, Status Quo Scenario, 5\% New Housing Growth

\begin{tabular}{|c|c|c|c|c|c|c|c|c|c|c|c|c|}
\hline \multirow[b]{3}{*}{ Year } & \multicolumn{6}{|c|}{$\begin{array}{l}\text { New House/Old House ESR Curve Sensitivity Applications Based on Segment of } \\
\text { Population Group in New or Old House }\end{array}$} & \multicolumn{6}{|c|}{ New House ESR Curve Sensitivity Applied Evenly to All Groups } \\
\hline & \multicolumn{2}{|c|}{ Majority } & \multicolumn{2}{|c|}{ Black } & \multicolumn{2}{|c|}{ Hispanic } & \multicolumn{2}{|c|}{ Majority } & \multicolumn{2}{|c|}{ Black } & \multicolumn{2}{|c|}{ Hispanic } \\
\hline & $\begin{array}{c}\text { Consump- } \\
\text { tion }^{\mathbf{a}}\end{array}$ & $\begin{array}{c}\text { Expendi- } \\
\text { ture }\end{array}$ & $\begin{array}{l}\text { Consump- } \\
\text { tion }\end{array}$ & $\begin{array}{l}\text { Expendi- } \\
\text { ture }\end{array}$ & $\begin{array}{l}\text { Consump- } \\
\text { tion }\end{array}$ & $\begin{array}{l}\text { Expendi- } \\
\text { ture }\end{array}$ & $\begin{array}{l}\text { Consump- } \\
\text { tion }\end{array}$ & $\begin{array}{l}\text { Expendi- } \\
\text { ture }\end{array}$ & $\begin{array}{c}\text { Consump- } \\
\text { tion }\end{array}$ & $\begin{array}{l}\text { Expendi- } \\
\text { ture }\end{array}$ & $\begin{array}{l}\text { Consump- } \\
\text { tion }\end{array}$ & $\begin{array}{l}\text { Expendi- } \\
\text { ture }\end{array}$ \\
\hline 1987 & 99.9 & $1,268.8$ & 110.3 & $1,354.6$ & 86.8 & $1,189.4$ & 99.7 & $1,267.1$ & 110.1 & $1,352.4$ & 86.7 & $1,187.6$ \\
\hline 1989 & 103.4 & $1,184.3$ & 113.2 & $1,258.4$ & 91.0 & $1,097.5$ & 102.8 & $1,178.0$ & 112.4 & $1,250.3$ & 90.5 & $1,090.7$ \\
\hline 1991 & 101.9 & $1,208.5$ & 112.7 & $1,312.3$ & 87.6 & $1,107.6$ & 100.4 & $1,191.0$ & 110.6 & $1,288.6$ & 86.1 & $1,089.3$ \\
\hline 1993 & 100.6 & $1,215.4$ & 112.7 & $1,317.7$ & 88.9 & $1,139.8$ & 97.6 & $1,182.3$ & 108.6 & $1,271.1$ & 86.0 & $1,104.1$ \\
\hline 1995 & 98.7 & $1,261.4$ & 110.4 & $1,360.4$ & 88.2 & $1,188.3$ & 94.6 & $1,212.7$ & 104.4 & $1,289.3$ & 83.9 & $1,131.4$ \\
\hline 1997 & 95.9 & $1,394.7$ & 108.1 & $1,515.9$ & 85.4 & $1,303.4$ & 91.3 & $1,333.7$ & 101.2 & $1,421.7$ & 80.5 & $1,230.8$ \\
\hline 1999 & 93.9 & $1,530.6$ & 107.3 & $1,718.6$ & 86.3 & $1,480.7$ & 89.5 & $1,465.8$ & 100.5 & $1,614.3$ & 81.4 & $1,398.8$ \\
\hline 2001 & 92.4 & $1,415.3$ & 106.4 & $1,566.9$ & 85.3 & $1,356.5$ & 89.0 & $1,368.3$ & 100.5 & $1,484.3$ & 81.0 & $1,293.3$ \\
\hline 2003 & 90.8 & $1,269.9$ & 103.6 & $1,347.2$ & 83.3 & $1,192.3$ & 88.4 & $1,241.3$ & 99.4 & $1,296.4$ & 80.0 & $1,152.7$ \\
\hline 2005 & 89.2 & $1,252.3$ & 103.7 & $1,339.1$ & 83.2 & $1,174.8$ & 87.9 & $1,236.7$ & 101.0 & $1,309.8$ & 81.2 & $1,151.7$ \\
\hline 2007 & 87.5 & $1,291.8$ & 100.0 & $1,391.2$ & 82.3 & $1,227.9$ & 87.0 & $1,286.0$ & 99.0 & $1,379.5$ & 81.3 & $1,214.1$ \\
\hline 2009 & 84.9 & $1,362.8$ & 97.2 & $1,504.7$ & 79.3 & $1,292.8$ & 84.8 & $1,363.4$ & 97.2 & $1,505.6$ & 79.3 & $1,294.9$ \\
\hline Total Con- & 1,139 & & 1,286 & & 1,028 & & 1,113 & & 1,245 & & 998 & \\
\hline $\begin{array}{l}\text { sumption } \\
\text { Discounted } \\
\text { Expenditure }\end{array}$ & & 11,992 & & 13,001 & & 11,285 & & 11,740 & & 12,603 & & 10,973 \\
\hline
\end{tabular}

- $10^{6} \mathrm{Btu} / \mathrm{yr}$ per household.

b \$/yr per household. 
TABLE 3 Electricity Consumption and Expenditures, Status Quo Scenario, 5\% New Housing Growth

\begin{tabular}{|c|c|c|c|c|c|c|c|c|c|c|c|c|}
\hline \multirow[b]{3}{*}{ Year } & \multicolumn{6}{|c|}{$\begin{array}{c}\text { New House/Old House ESR Curve Sensitivity Applications Based on Segment of } \\
\text { Population Group in New or Old House }\end{array}$} & \multicolumn{6}{|c|}{ New House ESR Curve Sensitivity Applied Evenly to All Groups } \\
\hline & \multicolumn{2}{|c|}{ Majority } & \multicolumn{2}{|c|}{ Black } & \multicolumn{2}{|c|}{ Hispanic } & \multicolumn{2}{|c|}{ Majority } & \multicolumn{2}{|c|}{ Black } & \multicolumn{2}{|c|}{ Hispanic } \\
\hline & $\begin{array}{c}\text { Consump- } \\
\text { tion }^{\mathbf{a}}\end{array}$ & $\begin{array}{c}\text { Expendi- } \\
\text { ture }^{b}\end{array}$ & $\begin{array}{c}\text { Consump- } \\
\text { tion }\end{array}$ & $\begin{array}{c}\text { Expendi- } \\
\text { ture }\end{array}$ & $\begin{array}{c}\text { Consump- } \\
\text { tion }\end{array}$ & $\begin{array}{c}\text { Expendi- } \\
\text { ture }\end{array}$ & $\begin{array}{c}\text { Consump- } \\
\text { tion }\end{array}$ & $\begin{array}{l}\text { Expendi- } \\
\text { ture }\end{array}$ & $\begin{array}{l}\text { Consump- } \\
\text { tion }\end{array}$ & $\begin{array}{c}\text { Expendi- } \\
\text { ture }\end{array}$ & $\begin{array}{c}\text { Consump- } \\
\text { tion }\end{array}$ & $\begin{array}{c}\text { Expendi- } \\
\text { ture }\end{array}$ \\
\hline 1987 & 31.5 & 758.1 & 27.3 & 695.8 & 26.1 & 705.5 & 31.5 & 757.3 & 27.3 & 694.9 & 26.1 & 704.5 \\
\hline 1989 & 33.1 & 713.7 & 28.6 & 651.4 & 26.6 & 645.2 & 33.0 & 710.4 & 28.4 & 647.4 & 26.4 & 641.1 \\
\hline 1991 & 33.6 & 711.8 & 29.5 & 662.4 & 27.2 & 648.0 & 33.2 & 702.6 & 29.0 & 651.6 & 26.7 & 637.8 \\
\hline 1993 & 34.3 & 730.1 & 29.2 & 660.7 & 27.2 & 655.6 & 33.5 & 712.8 & 28.3 & 639.1 & 26.5 & 636.8 \\
\hline 1995 & 34.1 & 771.4 & 29.3 & 701.3 & 27.9 & 705.2 & 33.0 & 745.3 & 27.9 & 666.7 & 26.6 & 672.9 \\
\hline 1997 & 34.6 & 858.3 & 29.4 & 774.3 & 26.4 & 744.2 & 33.4 & 826.8 & 27.8 & 731.1 & 25.0 & 704.9 \\
\hline 1999 & 35.7 & 906.2 & 30.7 & 832.0 & 27.6 & 796.5 & 34.5 & 875.5 & 29.1 & 788.1 & 26.2 & 755.7 \\
\hline 2001 & 35.4 & 887.3 & 29.1 & 776.3 & 27.6 & 773.6 & 34.5 & 863.2 & 27.8 & 740.8 & 26.6 & 743.0 \\
\hline 2003 & 34.5 & 842.4 & 27.5 & 715.1 & 26.4 & 733.8 & 33.9 & 828.0 & 26.7 & 692.8 & 25.7 & 712.7 \\
\hline 2005 & 35.3 & 837.4 & 27.6 & 701.3 & 26.1 & 702.9 & 35.0 & 830.7 & 27.2 & 690.5 & 25.6 & 687.5 \\
\hline 2007 & 36.4 & 837.2 & 28.4 & 696.2 & 26.5 & 692.6 & 36.3 & 835.1 & 28.3 & 692.8 & 26.4 & 688.8 \\
\hline 2009 & 37.6 & 869.5 & 29.2 & 720.4 & 27.1 & 711.1 & 37.7 & 870.8 & 29.4 & 724.4 & 27.2 & 713.6 \\
\hline Total Con- & 416 & & 346 & & 323 & & 410 & & 337 & & 315 & \\
\hline $\begin{array}{l}\text { sumption } \\
\text { Discounted } \\
\text { Expenditure }\end{array}$ & & 7,406 & & 6,582 & & 6,525 & & 7,279 & & 6,408 & & 6,362 \\
\hline
\end{tabular}

a $10^{6} \mathrm{Btw} / \mathrm{yr}$ per household.

b $\$$ yr per household. 
Comparing the N/O with the $\mathrm{N}$ case for electricity consumption, we found that the majority subgroup consumed $1.6 \%$ more in the $\mathrm{N} / \mathrm{O}$ case than in the $\mathrm{N}$ case, the black subgroup consumed 2.6\% more, and the Hispanic subgroup consumed $2.4 \%$ more. The average black subgroup member was farthest from his/her ideal compared with the average members of the other two subgroups. Energy expenditure tends to rise and fall with consumption, and the majority subgroup's electricity expenditures were $1.7 \%$ higher in the $\mathrm{N} / \mathrm{O}$ case than in the $\mathrm{N}$ case, the black subgroup's electricity expenditures were $2.7 \%$ higher, and the Hispanic subgroup's electricity expenditures were $2.6 \%$ higher. The fact that the Hispanic subgroup was paying relatively more per $10^{6}$ Btu than the other subgroups may possibly reflect the Hispanic subgroup's regional dispersion compared to the other two groups, with the corresponding regional differences in electricity prices. It may also be reflective of the timing in electricity consumption if variable (time-of-use and seasonal) rate structures exist in some areas, and the weight of the customer charge relative to the energy charge in one's electric bill. In terms of expenditure, the Hispanic subgroup was 0.1 percentage point closer to its ideal than the black subgroup was and 0.9 percentage points farther from its ideal than the majority subgroup was. The black subgroup was one full percentage point farther from its ideal than the majority subgroup was.

In terms of total energy consumed, using the table of differences of the N/O from the reference case (Table 4), the net difference was highest for the black subgroup, at $17.37 \times 10^{6} \mathrm{Btu}$; second-highest for the Hispanic subgroup, at $14.12 \times 10^{6} \mathrm{Btu}$; and lowest for the majority subgroup, at $7.24 \times 10^{6}$ Btu. All subgroups consumed more total energy under the N/O case than under the reference case because for each subgroup, the portion of the subgroup that was sensitive to the Old House ESR curve was worse off than it was under the assumed average ESR pattern in the reference case. Although the new house residents were better off, there were enough old house residents in the N/O case to render each subgroup worse off than in the reference case. In the attempt to model a more realistic ESR curve in the N/O case, essentially controlling for age of the housing structure, we found that more energy was consumed than had been consumed previously by all subgroups.

Comparing groups to see how they fared under the more realistic N/O case relative to the reference case, we saw dramatic differences in energy consumption. The undiscounted difference in total energy consumption for the black subgroup was $139.9 \%$ higher than that for the majority subgroup, the Hispanic subgroup was $95 \%$ higher than the majority, and the black subgroup was $23 \%$ higher than the Hispanic subgroup.

In terms of total energy expenditure, for the black agent the discounted difference in the N/O case relative to the reference case was $198 \%$ higher than the majority. The difference was $134 \%$ higher for the Hispanic subgroup compared with the majority subgroup, and for the black subgroup, the difference was $27 \%$ higher than that of the Hispanic agent. 
TABLE 4 Total Energy Consumption and Expenditures, Minns the Reference Case, Status Quo Scenario, 5\% New Housing Growth

\begin{tabular}{|c|c|c|c|c|c|c|c|c|c|c|c|c|}
\hline \multirow[b]{3}{*}{ Year } & \multicolumn{6}{|c|}{$\begin{array}{l}\text { New House/Old House ESR Curve Sensitivity Based on Segment of Pcipuitation Group } \\
\text { in New or Old House }\end{array}$} & \multicolumn{6}{|c|}{ New House ESR Curve Sensitivity Applied Evenly to All Groups } \\
\hline & \multicolumn{2}{|c|}{ Majority } & \multicolumn{2}{|c|}{ Black } & \multicolumn{2}{|c|}{ Hispanic } & \multicolumn{2}{|c|}{ Majority } & \multicolumn{2}{|c|}{ Black } & \multicolumn{2}{|c|}{ Hispanic } \\
\hline & $\begin{array}{l}\text { Consump- } \\
\text { tion }\end{array}$ & $\begin{array}{l}\text { Expendi- } \\
\text { ture }\end{array}$ & $\begin{array}{c}\text { Consump- } \\
\text { tion }\end{array}$ & $\begin{array}{l}\text { Expendi- } \\
\text { ture }\end{array}$ & $\begin{array}{l}\text { Consump- } \\
\text { tion }\end{array}$ & $\begin{array}{l}\text { Expendi- } \\
\text { ture }\end{array}$ & $\begin{array}{c}\text { Consump- } \\
\text { tion }\end{array}$ & $\begin{array}{l}\text { Expendi- } \\
\text { ture }\end{array}$ & $\begin{array}{c}\text { Consump- } \\
\text { tion }\end{array}$ & $\begin{array}{l}\text { Expendi- } \\
\text { ture }\end{array}$ & $\begin{array}{l}\text { Consump- } \\
\text { tion }\end{array}$ & $\begin{array}{l}\text { Expendi- } \\
\text { ture }\end{array}$ \\
\hline 1987 & 0.00 & -0.05 & 0.00 & -0.02 & 0.00 & -0.03 & -0.20 & -0.18 & -0.18 & -0.18 & -0.12 & -0.18 \\
\hline 1989 & 0.58 & 0.56 & 0.71 & 0.70 & 0.66 & 0.65 & 0.00 & 0.03 & 0.00 & 0.06 & 0.11 & 0.03 \\
\hline 1991 & 0.99 & 0.94 & 1.35 & 1.29 & 1.27 & 1.16 & -0.50 & -0.53 & -0.54 & -0.54 & -0.46 & -0.51 \\
\hline 1993 & 1.21 & 0.95 & 1.81 & 1.78 & 1.48 & 1.32 & -1.81 & -1.80 & -1.90 & -1.82 & -1.83 & -1.86 \\
\hline 1995 & 1.13 & 0.81 & 2.32 & 2.19 & 1.85 & 1.77 & -3.07 & -3.08 & -3.24 & -3.15 & -3.12 & -3.10 \\
\hline 1997 & 1.16 & 0.74 & 2.76 & 2.63 & 2.15 & 2.01 & -3.69 & -3.66 & -3.80 & -3.74 & -3.71 & -3.67 \\
\hline 1999 & 1.08 & 0.76 & 2.78 & 2.61 & 2.25 & 2.13 & -3.66 & -3.50 & -3.74 & -3.62 & -3.55 & -3.52 \\
\hline 2001 & 0.87 & 0.52 & 2.70 & 2.49 & 2.03 & 1.82 & -2.84 & -2.82 & -2.99 & -2.91 & -3.11 & -2.92 \\
\hline 2003 & 0.39 & 0.12 & 1.67 & 1.61 & 1.59 & 1.10 & -2.32 & -2.14 & -2.45 & -2.22 & -2.44 & -2.26 \\
\hline 2005 & 0.00 & -0.09 & 1.07 & 0.81 & 0.60 & 0.59 & -1.46 & -1.33 & -1.56 & -1.39 & .1 .81 & -1.39 \\
\hline 2007 & -0.23 & -0.27 & 0.20 & 0.17 & 0.49 & 0.36 & -0.80 & -0.72 & -0.80 & -0.67 & -0.73 & -0.77 \\
\hline 2009 & 0.12 & 0.05 & 0.00 & -0.06 & .0 .25 & -0.24 & 0.00 & 0.10 & 0.00 & 0.00 & -0.25 & -0.08 \\
\hline Net Difference & 7.24 & 5.04 & 17.37 & 16.20 & 14.12 & 12.64 & -20.35 & -19.63 & -21.20 & -20.18 & -21.02 & -20.23 \\
\hline $\begin{array}{l}\text { Discounted } \\
\text { Difference }\end{array}$ & 5.88 & 4.21 & 13.39 & 12.54 & 10.94 & 9.84 & -15.28 & -14.79 & -15.92 & -15.18 & -15.65 & -15.19 \\
\hline
\end{tabular}


In the $\mathrm{N}$ case relative to the reference case, all subgroups saved because the new house ESR curve was nearly always better than the reference case ESR. Total energy consumption savings were approximately even across population subgroups, ranging from $\mathbf{- 2 0 . 3 5}$ for the majority subgroup to $\mathbf{- 2 1 . 2 0}$ for the black subgroup. The difference in consumption savings by the black subgroup was $4.2 \%$ higher than that of the majority subgroup. The consumption savings by the Hispanic subgroup was $3.3 \%$ higher than that of the majority subgroup, and for the black subgroup, it was $0.8 \%$ higher than that of the Hispanic subgroup. We found that if all groups faced ideal housing conditions, the savings of the black subgroup would be the highest, followed by the savings of the Hispanic subgroup. As demonstrated above, the relative differences across groups would be minor.

The discounted difference in total energy expenditure savings in the $N$ case was highest for the Hispanic agent, with savings that were $2.7 \%$ higher than those of the majority agent. The black agent's savings were $2.6 \%$ greater than those of the majority agent. From this we surmised that, if the members of the black and the Hispanic subgroups were all exposed to the new house energy-efficiency measures, these subgroups' potential for savings would be the greatest.

Comparing the difference in total energy consumption in the N/O versus the $\mathrm{N}$ cases, we found that the majority subgroup's consumption spread was $21.16 \times 10^{6} \mathrm{Btu}$, the black subgroup's spread was $29.31 \times 10^{6} \mathrm{Btu}$, and the Hispanic subgroup's spread was $26.59 \times 10^{6} \mathrm{Btu}$. The expenditure spread was $\$ 19.00$ for the majority subgroup, $\$ 27.72$ for the black subgroup, and $\$ 25.03$ for the Hispanic subgroup. The spread was substantially greater for the black than for the majority subgroup (38.5\% in consumption and $46 \%$ in expenditure). The spread was quite high for the Hispanic subgroup relative to the majority, $25.7 \%$ in consumption and $32 \%$ in expenditure. The black subgroup exceeded the Hispanic subgroup by $10.2 \%$ in consumption and $10.7 \%$ in expenditure.

In electricity consumption and expenditure, the differences between the $\mathrm{N} / \mathrm{O}$ and the reference case were all positive (Table 5), but not as high as they were for total energy. The discounted difference in electricity expenditure was highest for the black subgroup, at $\$ 9.58$; next-highest for the Hispanic $\mathrm{st}^{-1}$ group, at $\$ 8.28$; and lowest for the majority subgroup, at $\$ 1.54$.

In the $\mathrm{N}$ case relative to the reference case, all groups saved an equal amount of money on electricity. The discounted difference in electricity expenditure was $-\$ 14.56$ for the Hispanic subgroup, $-\$ 14.38$ for the black subgroup, and $-\$ 14.01$ for the majority subgroup. In the ideal $\mathrm{N}$ case, all groups saved about the same amount of money.

The spreads between savings on electricity in the $\mathrm{N} / \mathrm{O}$ case and savings in the $\mathrm{N}$ case are quite different across groups, with the black group's electricity consumption spread at $23.06 \times 10^{6} \mathrm{Btu}$, or $57 \%$ greater than the majority group's spread; the Hispanic group's spread at $22.15 \times 10^{6} \mathrm{Btu}$, or $50 \%$ greater than the majority group's spread; and the majority group's spread at $14.73 \times 10^{6} \mathrm{Btu}$. The expenditure spread for the black group was $\$ 23.96$, or $54 \%$ greater than the majority; for the Hispanic group, the spread was $\$ 22.84$, or $47 \%$ 
TABLE 5 Electricity Consumption and Expenditures, Minus the Reference Case, Status Quo Scenario, 5\% New Housing Growth

\begin{tabular}{|c|c|c|c|c|c|c|c|c|c|c|c|c|}
\hline \multirow[b]{3}{*}{ Year } & \multicolumn{6}{|c|}{$\begin{array}{l}\text { New House/Old House ESR Curve Sensitivity Based on Segment of Population } \\
\text { Group in New or Old House }\end{array}$} & \multicolumn{6}{|c|}{ New House ESR Curve Sensitivity Applied Evenly to All Groups } \\
\hline & \multicolumn{2}{|c|}{ Majority } & \multicolumn{2}{|c|}{ Black } & \multicolumn{2}{|c|}{ Hispanic } & \multicolumn{2}{|c|}{ Majority } & \multicolumn{2}{|c|}{ Black } & \multicolumn{2}{|c|}{ Hiepanic } \\
\hline & $\begin{array}{l}\text { Consump- } \\
\text { tion }\end{array}$ & $\begin{array}{c}\text { Expendi- } \\
\text { ture }\end{array}$ & $\begin{array}{l}\text { Consump- } \\
\text { tion }\end{array}$ & $\begin{array}{l}\text { Expendi- } \\
\text { ture }\end{array}$ & $\begin{array}{l}\text { Consump- } \\
\text { tion }\end{array}$ & $\begin{array}{l}\text { Expendi- } \\
\text { ture }\end{array}$ & $\begin{array}{c}\text { Consump- } \\
\text { tion }\end{array}$ & $\begin{array}{l}\text { Expendi- } \\
\text { ture }\end{array}$ & $\begin{array}{l}\text { Consump- } \\
\text { tion }\end{array}$ & $\begin{array}{c}\text { Expendi- } \\
\text { ture }\end{array}$ & $\begin{array}{l}\text { Consump- } \\
\text { tion }\end{array}$ & $\begin{array}{c}\text { Expendi- } \\
\text { ture }\end{array}$ \\
\hline 1987 & 0.00 & -0.05 & 0.00 & -0.03 & 0.00 & -0.04 & 0.00 & -0.16 & 0.00 & -0.16 & 0.00 & -0.18 \\
\hline 1989 & 0.30 & 0.52 & 0.70 & 0.68 & 0.76 & 0.62 & 0.00 & 0.06 & 0.00 & 0.06 & 0.00 & -0.02 \\
\hline 1991 & 0.60 & 0.82 & 1.03 & 1.15 & 1.12 & 1.08 & -0.60 & -0.48 & -0.68 & -0.50 & -0.74 & -0.51 \\
\hline 1993 & 0.59 & 0.61 & 1.39 & 1.51 & 0.74 & 1.03 & -1.76 & -1.78 & -1.74 & -1.81 & -1.85 & -1.86 \\
\hline 1995 & 0.29 & 0.25 & 1.74 & 1.76 & 1.45 & 1.53 & -2.94 & -3.14 & -3.12 & -3.26 & -3.27 & -3.12 \\
\hline 1997 & 0.00 & 0.09 & 2.08 & 2.00 & 1.54 & 1.74 & -3.47 & -3.58 & -3.47 & -3.69 & -3.85 & -3.64 \\
\hline 1999 & 0.00 & 0.09 & 1.99 & 2.04 & 1.85 & 1.91 & -3.36 & -3.30 & -3.32 & -3.35 & -3.32 & $-\mathbf{3 . 3 1}$ \\
\hline 2001 & -0.28 & -0.01 & 1.75 & 1.89 & 1.10 & 1.32 & -2.82 & -2.73 & -2.80 & -2.77 & -2.56 & -2.69 \\
\hline 2003 & -0.29 & -0.17 & 1.10 & 0.99 & 1.15 & 1.07 & -2.02 & -1.87 & -1.84 & -2.16 & -1.53 & -1.83 \\
\hline 2005 & -0.56 & -0.39 & 0.36 & 0.31 & 0.38 & 0.51 & -1.41 & -1.19 & -1.09 & -1.23 & -1.54 & -1.69 \\
\hline 2007 & -0.27 & -0.24 & 0.00 & 0.01 & 0.00 & -0.07 & -0.55 & -0.49 & -0.35 & -0.47 & -0.38 & -0.62 \\
\hline 2009 & 0.00 & 0.01 & 0.00 & -0.15 & 0.00 & -0.15 & 0.27 & 0.16 & 0.68 & 0.40 & 0.37 & 0.20 \\
\hline Net Difference & 0.38 & 1.53 & 12.14 & 12.16 & 10.09 & 10.55 & -18.66 & -18.50 & -17.73 & -18.94 & -18.67 & -19.27 \\
\hline $\begin{array}{l}\text { Discounted } \\
\text { Difference }\end{array}$ & 0.66 & 1.54 & 9.51 & 9.58 & 7.92 & 8.28 & -14.07 & -14.01 & -13.55 & -14.38 & -14.23 & -14.56 \\
\hline
\end{tabular}


greater than the majority; and for the majority, the spread was $\$ 15.55$. The electricity expenditure spread of the black subgroup was $4.9 \%$ greater than the spread of the Hispanic subgroup. Positive values indicate a welfare loss, so both black and Hispanic subgroups fared substantially worse than the majority subgroup in electricity expenditure.

Trends in total energy use showed a decline in total energy consumption over the 22-year period for both the $\mathrm{N} / \mathrm{O}$ and $\mathrm{N}$ cases, with greater percentage-change declines found in the $N$ case than in the N/O case (see Table 6). The time pattern of total energy consumption declines was evident in the comparison in N/O vs. $\mathrm{N}$ cases. Declines were initially much sharper in the $\mathrm{N}$ case.

The energy consumption savings, using trends, were found to be greater (i.e., more negative) for all groups under the $\mathrm{N}$ case than under the N/O case. Expenditure trends in both the N/O and the $\mathrm{N}$ cases increased, with a higher trend in the N/O case for all groups. These two results are consistent with expectations. Although consumption declines, future price increases must have been combined with own-price demand elasticities of less than one to account for the upward trend in energy expenditure.

The trend (discounted net percent change) for the black subgroup's savings in energy consumption over the 22-year period was $15.8 \%$ higher under the $\mathrm{N}$ case than under the N/O case. The trend for the Hispanic subgroup's savings in energy consumption was $22.8 \%$ higher under the $\mathrm{N}$ case than it was under the N/O case. The trend for the majority subgroup's savings in energy consumption was $8 \%$ higher under the $\mathrm{N}$ case than it was under the N/O case. The energy-expenditure trend is not a savings, but a cost, and its increase was $14.6 \%$ lower in the $\mathrm{N}$ case vs. the N/O case for the Hispanic subgroup, 13.4\% lower for the black subgroup, and $13.7 \%$ lower for the majority subgroup. The expenditure trend is less predictable than other outcomes and might be counterintuitive. In viewing the 1987-2009 percent change (an undiscounted trend), the $\mathrm{N}$ vs. the N/O case percent change is essentially the same in a particular subgroup. Since the ESR in both the N and N/O cases declines to 0.9155 , any undiscounted trends would be nearly identical.

Comparing the trends of the subgroups in the N/O case, we found that the trend for savings in energy consumption was $26.8 \%$ slower for the black subgroup than for the majority subgroup and $52.6 \%$ slower for the Hispanic subgroup than for the majority agent. We found that the trend for increases in energy expenditure was $52.1 \%$ higher for the black subgroup than for the majority subgroup, and 20.9\% higher for the Hispanic subgroup than for the majority subgroup. In the $\mathrm{N}$ case, the rates were similar, with the trends for energy consumption savings $21.5 \%$ and $46.1 \%$ slower for the black and Hispanic subgroups, respectively, vis-a-vis the majority subgroup. The $\mathrm{N}$ case trends for energy-expenditure increases were $52.7 \%$ and $19.6 \%$ higher for the black and Hispanic subgroups, respectively, in contrast to the majority subgroup.

Electricity consumption and expenditure trends were positive for all subgroups, and they were higher under the $\mathrm{N} / \mathrm{O}$ case than under the $\mathrm{N}$ case (see Table 7). In comparing subgroups, we found that the majority's trends ware much higher than those of the other two 
TABLE 6 Total Energy Consumption Trends, Status Quo Scenario, 5\% New Housing Growth (\% Change)

\begin{tabular}{|c|c|c|c|c|c|c|c|c|c|c|c|c|}
\hline \multirow[b]{3}{*}{ Year } & \multicolumn{6}{|c|}{$\begin{array}{l}\text { New House/Old House ESR Curve Sensitivity Based on Segment of Population } \\
\text { Group in New or Old House }\end{array}$} & \multicolumn{6}{|c|}{ New House ESR Curve Sensitivity Applied Evenly to All Groups } \\
\hline & \multicolumn{2}{|c|}{ Majority } & \multicolumn{2}{|c|}{ Black } & \multicolumn{2}{|c|}{ Hiepanic } & \multicolumn{2}{|c|}{ Majority } & \multicolumn{2}{|c|}{ Black } & \multicolumn{2}{|c|}{ Hispanic } \\
\hline & $\begin{array}{l}\text { Consump- } \\
\text { tion }\end{array}$ & $\begin{array}{c}\text { Expendi- } \\
\text { ture }\end{array}$ & $\begin{array}{c}\text { Consump- } \\
\text { tion }\end{array}$ & $\begin{array}{c}\text { Expendi- } \\
\text { ture }\end{array}$ & $\begin{array}{l}\text { Consump- } \\
\text { tion }\end{array}$ & $\begin{array}{l}\text { Expendi- } \\
\text { ture }\end{array}$ & $\begin{array}{l}\text { Consump- } \\
\text { tion }\end{array}$ & $\begin{array}{l}\text { Expendi- } \\
\text { ture }\end{array}$ & $\begin{array}{l}\text { Consump- } \\
\text { tion }\end{array}$ & $\begin{array}{l}\text { Expendi- } \\
\text { ture }\end{array}$ & $\begin{array}{c}\text { Consump- } \\
\text { tion }\end{array}$ & $\begin{array}{l}\text { Expendi- } \\
\text { ture }\end{array}$ \\
\hline 1989 & 3.50 & -6.66 & 2.63 & -7.10 & 4.84 & -7.73 & 3.11 & -7.03 & 2.09 & -7.55 & 4.38 & -8.16 \\
\hline 1991 & -1.45 & 2.04 & -0.44 & 4.28 & -3.74 & 0.92 & -2.33 & 1.10 & -1.60 & 3.06 & -4.86 & -0.13 \\
\hline 1993 & -1.28 & 0.57 & 0.00 & 0.41 & 1.48 & 2.91 & -2.79 & -0.73 & -1.81 & -1.36 & -0.12 & 1.36 \\
\hline 1995 & -1.89 & 3.78 & -2.04 & 3.24 & -0.79 & 4.26 & -3.07 & 2.57 & -3.87 & 1.43 & -2.44 & 2.47 \\
\hline 1997 & -2.84 & 10.57 & -2.08 & 11.43 & -3.17 & 9.69 & -3.49 & 9.98 & -3.07 & 10.27 & -4.05 & 8.79 \\
\hline 1999 & -2.09 & 9.74 & -0.74 & 13.37 & 1.05 & 13.60 & -1.97 & 9.90 & -0.69 & 13.55 & 1.12 & 13.65 \\
\hline 2001 & -1.60 & -7.53 & -0.84 & -8.83 & -1.16 & -8.39 & -0.56 & -6.65 & 0.00 & -8.05 & -0.49 & -7.54 \\
\hline 2003 & -1.73 & -10.27 & -2.63 & -14.02 & -2.34 & -12.10 & -0.67 & -9.28 & -1.09 & -12.66 & -1.23 & -10.87 \\
\hline 2005 & -1.76 & -1.39 & 0.10 & -0.60 & -0.12 & -1.47 & -0.57 & -0.37 & 1.61 & 1.03 & 1.50 & -0.09 \\
\hline 2007 & -1.91 & 3.15 & -3.57 & 3.89 & -1.08 & 4.52 & -1.02 & 3.99 & -1.98 & 5.32 & 0.12 & 5.42 \\
\hline 2009 & -2.97 & 5.50 & -2.80 & 8.16 & -3.65 & 5.29 & -2.53 & 6.02 & -1.82 & 9.14 & -2.46 & 6.66 \\
\hline $\begin{array}{l}\text { Discounted } \\
\text { Net \% Change }\end{array}$ & -10.66 & 6.62 & -7.80 & 8.00 & -5.05 & 8.00 & -11.51 & 5.71 & -9.03 & 8.72 & -6.20 & 6.83 \\
\hline $\begin{array}{l}\text { 1987-2009 } \\
\text { \% Change }\end{array}$ & -15.02 & 7.41 & -11.88 & 11.08 & -8.64 & 8.69 & -14.94 & 7.60 & -11.72 & 11.33 & -8.54 & 9.04 \\
\hline
\end{tabular}


TABLE 7 Electricity Consumption Trends, Status Quo Scenario, 5\% New Housing Growth (\% Change)

\begin{tabular}{|c|c|c|c|c|c|c|c|c|c|c|c|c|}
\hline \multirow[b]{3}{*}{ Year } & \multicolumn{6}{|c|}{$\begin{array}{l}\text { New House/Old House ESR Curve Sensitivity Based on Segment of Population } \\
\text { Group in New or Old House }\end{array}$} & \multicolumn{6}{|c|}{ New House ESR Curve Sensitivity Applied Evenly to All Groups } \\
\hline & \multicolumn{2}{|c|}{ Majority } & \multicolumn{2}{|c|}{ Black } & \multicolumn{2}{|c|}{ Hispanic } & \multicolumn{2}{|c|}{ Majority } & \multicolumn{2}{|c|}{ Black } & \multicolumn{2}{|c|}{ Hispanic } \\
\hline & $\begin{array}{l}\text { Consump- } \\
\text { tion }\end{array}$ & $\begin{array}{l}\text { Expendi- } \\
\text { ture }\end{array}$ & $\begin{array}{l}\text { Consump- } \\
\text { tion }\end{array}$ & $\begin{array}{l}\text { Expendi- } \\
\text { ture }\end{array}$ & $\begin{array}{c}\text { Consump- } \\
\text { tion }\end{array}$ & $\begin{array}{c}\text { Expendi- } \\
\text { ture }\end{array}$ & $\begin{array}{l}\text { Consump- } \\
\text { tion }\end{array}$ & $\begin{array}{l}\text { Expendi- } \\
\text { ture }\end{array}$ & $\begin{array}{c}\text { Consump- } \\
\text { tion }\end{array}$ & $\begin{array}{l}\text { Expendi- } \\
\text { ture }\end{array}$ & $\begin{array}{l}\text { Consump- } \\
\text { tion }\end{array}$ & $\begin{array}{l}\text { Expendi- } \\
\text { ture }\end{array}$ \\
\hline 1989 & 6.08 & -5.86 & 4.76 & -6.38 & 1.92 & -8.55 & 4.76 & -6.19 & 4.03 & -6.84 & 1.15 & -9.00 \\
\hline 1991 & 1.51 & -0.27 & 3.15 & 1.69 & 2.26 & 0.43 & 0.61 & -1.10 & 2.11 & 0.65 & 1.14 & -0.51 \\
\hline 1993 & 2.08 & 2.57 & -1.02 & -0.26 & 0.00 & 1.17 & 0.90 & 1.45 & -2.41 & -1.92 & -0.75 & -0.16 \\
\hline 1995 & -0.58 & 5.66 & 0.34 & 6.14 & 2.57 & 7.57 & -1.49 & 4.56 & -1.41 & 4.32 & 0.38 & 5.67 \\
\hline 1997 & 1.47 & 11.27 & 0.34 & 10.41 & -5.38 & 5.53 & 1.21 & 10.94 & -0.36 & 9.66 & -6.02 & 4.76 \\
\hline 1999 & 3.18 & 5.58 & 4.42 & 7.45 & 4.55 & 7.03 & 3.29 & 5.89 & 4.68 & 7.80 & 4.80 & 7.21 \\
\hline 2001 & -0.84 & -2.09 & -5.21 & -6.69 & 0.00 & -2.88 & 0.00 & -1.40 & -4.47 & -6.00 & 1.53 & -1.68 \\
\hline 2003 & -2.54 & -5.06 & -5.50 & -7.88 & -4.35 & -5.14 & -1.74 & -4.08 & -3.96 & -6.48 & -3.38 & -4.08 \\
\hline 2005 & 2.32 & -0.59 & 0.36 & -1.93 & -1.14 & -4.21 & 3.24 & 0.33 & 1.87 & -0.33 & -0.39 & -3.54 \\
\hline 2007 & 3.12 & -0.02 & 2.90 & -0.73 & 1.53 & -1.47 & 3.71 & 0.53 & 4.04 & 0.33 & 3.13 & 0.19 \\
\hline 2009 & 3.30 & 3.86 & 2.82 & 3.48 & 2.26 & 2.67 & 3.86 & 4.27 & 3.89 & 4.56 & 3.03 & 3.60 \\
\hline $\begin{array}{l}\text { Discounted Net } \\
\text { \% Change }\end{array}$ & 14.02 & 10.93 & 6.63 & 4.27 & 3.77 & 1.48 & 13.42 & 10.28 & 5.84 & 3.37 & 2.90 & 0.57 \\
\hline $\begin{array}{l}1987-2009 \\
\% \text { Change }\end{array}$ & 19.37 & 14.69 & 6.96 & 3.54 & 3.83 & 0.79 & 19.68 & 14.99 & 7.69 & 4.25 & 4.21 & 1.29 \\
\hline
\end{tabular}


subgroups. The electricity usage of the majority agent increased faster, and the total energy use of the majority agent decreased faster, than those of the other two groups. A possible explanation for this is a greater proportion of all-electric homes among majority subgroup members, together with a greater discretionary demand for electric appliances over time within the majority subgroup. The $\mathrm{N}$ case trend in electricity usage by the majority subgroup was lower than that of the N/O case, indicating the ESR effect.

In the $\mathrm{N} / \mathrm{O}$ case, the trend in electricity consumption for the black subgroup was $52.7 \%$ slower than for the majority; for the Hispanic subgroup, it was $73.1 \%$ slower. The N/O-case trend in electricity expenditure for the black subgroup was $61 \%$ slower, and for the Hispanic subgroup it was $86 \%$ slower, than for the majority subgroup. In the $N$ case, the trend in electricity consumption was $56 \%$ and $78 \%$ slower for black and Hispanic subgroups, respectively, vis-a-vis the majority subgroup. The $\mathrm{N}$ case trend for electricity expenditure was $67 \%$ and $94 \%$ slower for black and Hispanic subgroups, respectively. Majority subgroups did better in consumption in the $\mathrm{N}$ case relative to the $\mathrm{N} / \mathrm{O}$ case by $4.2 \%$, black subgroups did better by $12 \%$, and Hispanic subgroups by $23 \%$. Majority subgroups did better in expenditure in the $\mathrm{N}$ case relative to the $\mathrm{N} / \mathrm{O}$ case by $6 \%$, black subgroups did better by $21 \%$, and Hispanic subgroups by $61 \%$.

Given that the trends in the N/O and N cases bracket the trends in the reference case, the differences among subgroups were similar to what they were in the reference case (noting that trends in the Hispanic, black, and majority subgroup's total electricity consumption and expenditure went from high to highest, respectively). The fact that a representative group member would have a low trend did not appear to reduce that member's relative rank in consumption and expenditure for the 22-year forecast period. 


\section{RESULTS FROM THE 4\% NEW HOUSING GROWTH SCENARIO}

Under the federal energy policy scenarios, as described in the National Energy Strategy (NES) of 1991/1992, the effect on the energy future of the United States of a potential set of policies being enacted prior to September 1990 is considered. The NES includes a wide range of policy choices that affect both the production and the consumption of energy. These choices lead to specific outcomes, in terms of the level of primary energy consumed and its composition. The status quo scenario is itself an NES scenario, which might be termed NES5 because of its use of a 5\% annual growth rate in new housing. Comparisons across scenarios will be fairly uniform, with the exception of a difference in new housing growth and a corresponding uniform rate of all-electric home growth. These comparisons will be based on the effects of new housing growth rates and their corresponding effect on household energy choices.

The published NES household energy consumption is projected at the aggregate level, without regional or demographic detail, and so it does not allow us to determine potential differences in the effect of the NES on different population groups. In a report by D.A. Poyer (1991), a detailed analysis of the disaggregate effect on minority households of the projections discussed in the NES was presented. Our study follows the Poyer study, and the outcomes are predicated upon an initial set of Poyer's energy demand parameters.

As predicted for both the N/O and N cases, the NES4 total energy consumption and expenditure is higher than that of the status quo scenario (see Table 8). The total energy consumption for the black subgroup in the N/O case was $0.7 \%$ higher in NES4 than in the status quo case; for the Hispanic subgroup, it was $0.7 \%$ higher; and for the majority subgroup, it was $1.5 \%$ higher. The black subgroup consumed $11.6 \%$ more than the majority subgroup and $25 \%$ more than the Hispanic subgroup; the majority subgroup consumed $12 \%$ more than the Hispanic subgroup. In the $\mathbf{N}$ case, the black and Hispanic subgroups consumed $10.7 \%$ and $11.4 \%$ more than the majority subgroup, respectively. Across cases, the black subgroup's consumption was $3.2 \%$ higher in the N/O case than in the $\mathrm{N}$ case, the Hispanic subgroup's consumption was $2.9 \%$ higher, and the majority subgroup's consumption was $2.5 \%$ higher.

The total energy expenditure for the black subgroup in the N/O case was $0.5 \%$ higher in NES4 than in the status quo; for the Hispanic subgroup, it was $0.6 \%$ higher; and for the majority subgroup, it was $0.7 \%$ higher. The black subgroup spent $8.2 \%$ more than the majority subgroup and 15\% more than the Hispanic subgroup, and the majority subgroup spent 6\% more than the Hispanic subgroup. In the $\mathrm{N}$ case, the black and Hispanic subgroups spent $7.4 \%$ and $6.5 \%$ less than the majority subgroup, respectively. Across cases, the black subgroup's expenditure was $3.2 \%$ higher in the $\mathrm{N} / \mathrm{O}$ case than in the $\mathrm{N}$ case, the Hispanic subgroup's expenditure was $2.9 \%$ higher, and the majority subgroup's expenditure was $2.5 \%$ higher. 
TABLE 8 Total Energy Consumption and Expenditures, NES4 Scenario, 4\% New Housing Growth

\begin{tabular}{|c|c|c|c|c|c|c|c|c|c|c|c|c|}
\hline \multirow[b]{3}{*}{ Year } & \multicolumn{6}{|c|}{$\begin{array}{l}\text { New House/Old House ESR Curve Sensitivity Based on Segment of Population } \\
\text { Group in New or Old House }\end{array}$} & \multicolumn{6}{|c|}{ New House ESR Curve Sensitivity Applied Evenly to All Groups } \\
\hline & \multicolumn{2}{|c|}{ Majority } & \multicolumn{2}{|c|}{ Black } & \multicolumn{2}{|c|}{ Hispanic } & \multicolumn{2}{|c|}{ Majority } & \multicolumn{2}{|c|}{ Black } & \multicolumn{2}{|c|}{ Hispanic } \\
\hline & $\begin{array}{c}\text { Consump- } \\
\text { tion }^{\mathrm{a}}\end{array}$ & $\begin{array}{c}\text { Expendi- } \\
\text { ture }^{b}\end{array}$ & $\begin{array}{c}\text { Consump- } \\
\text { tion }\end{array}$ & $\begin{array}{c}\text { Expendi- } \\
\text { ture }\end{array}$ & $\begin{array}{c}\text { Consump- } \\
\text { tion }\end{array}$ & $\begin{array}{c}\text { Expendi- } \\
\text { ture }\end{array}$ & $\begin{array}{l}\text { Consump- } \\
\text { tion }\end{array}$ & $\begin{array}{l}\text { Expendi- } \\
\text { ture }\end{array}$ & $\begin{array}{l}\text { Consump- } \\
\text { tion }\end{array}$ & $\begin{array}{l}\text { Expendi- } \\
\text { ture }\end{array}$ & $\begin{array}{l}\text { Consump- } \\
\text { tion }\end{array}$ & $\begin{array}{l}\text { Expendi- } \\
\text { ture }\end{array}$ \\
\hline 1987 & 99.9 & $1,268.8$ & 110.3 & $1,354.6$ & 86.8 & $1,189.4$ & 99.7 & $1,267.1$ & 110.1 & $1,352.4$ & 86.7 & $1,187.6$ \\
\hline 1989 & 103.7 & $1,184.9$ & 113.2 & $1,259.0$ & 91.1 & $1,098.2$ & 103.1 & $1,178.4$ & 112.5 & $1,251.0$ & 90.6 & $1,091.4$ \\
\hline 1991 & 102.4 & $1,210.4$ & 112.9 & $1,313.7$ & 87.8 & $1,109.9$ & 100.8 & $1,192.5$ & 110.8 & $1,290.0$ & 86.3 & $1,091.4$ \\
\hline 1993 & 101.4 & $1,218.7$ & 113.1 & $1,320.4$ & 89.2 & $1,142.0$ & 98.3 & $1,184.2$ & 109.0 & $1,273.4$ & 86.2 & $1,105.7$ \\
\hline 1995 & 99.9 & $1,266.6$ & 110.9 & $1,364.6$ & 88.6 & $1,192.1$ & 95.5 & $1,215.0$ & 104.8 & $1,292.5$ & 84.2 & $1,133.8$ \\
\hline 1997 & 97.5 & $1,404.5$ & 108.8 & $1,522.6$ & 86.1 & $1,311.0$ & 92.5 & $1, \mathbf{3 3 8 . 4}$ & 101.7 & $1,426.7$ & 81.1 & $1,236.1$ \\
\hline 1999 & 95.8 & $1,546.3$ & 108.1 & $1,728.4$ & 87.0 & $1,491.1$ & 91.0 & $1,474.4$ & 101.1 & $1,621.6$ & 81.9 & $1,406.1$ \\
\hline 2001 & 94.6 & $1,428.5$ & 107.3 & $1,576.1$ & 86.1 & $1,365.1$ & 91.0 & $1,375.0$ & 101.2 & $1,491.1$ & 81.7 & $1,299.0$ \\
\hline 2003 & 93.3 & $1,278.8$ & 104.8 & $1,356.2$ & 84.2 & $1,199.8$ & 90.5 & $1,245.4$ & 100.3 & $1,303.7$ & 80.7 & $1,158.1$ \\
\hline 2005 & 91.8 & $1,261.1$ & 104.8 & $1,348.6$ & 84.2 & $1,181.8$ & 90.1 & $1,242.3$ & 102.1 & $1,318.2$ & 82.0 & $1,157.2$ \\
\hline 2007 & 90.1 & $1,302.7$ & 101.3 & $1,404.6$ & 83.3 & $1,236.8$ & 89.4 & $1,295.5$ & 100.3 & $1,392.4$ & 82.2 & $1,222.1$ \\
\hline 2009 & 87.7 & $1,381.4$ & 98.7 & $1,523.6$ & 80.5 & $1,308.7$ & 87.6 & $1,382.1$ & 98.7 & $1,524.6$ & 80.5 & $1,311.0$ \\
\hline Total Con- & 1,158 & & 1,294 & & 1,035 & & 1,130 & & 1,253 & & 1,004 & \\
\hline $\begin{array}{l}\text { sumption } \\
\text { Discounted } \\
\text { Expenditure }\end{array}$ & & 12,072 & & 13,071 & & 11,348 & & 11,795 & & 12,666 & & 11,025 \\
\hline
\end{tabular}

Expenditure

a $10^{6} \mathrm{Btw} / \mathrm{yr}$ per household.

b \$yr per household. 
Electricity consumption, shown in Table 9 , for the black subgroup in the N/O case was $0.6 \%$ lower in NES4 than in the status quo; for the Hispanic subgroup, it was $0.3 \%$ lower; and for the majority subgroup, it was $1.5 \%$ lower. The black subgroup consumed $15.7 \%$ less than the majority subgroup and $7 \%$ more than the Hispanic subgroup, and the majority subgroup consumed $27 \%$ more than the Hispanic subgroup. In the $\mathrm{N}$ case, the black and Hispanic subgroups consumed $16 \%$ and $21 \%$ less than the majority subgroup, respectively. Across cases, the black subgroup's consumption was $2.3 \%$ higher in the $\mathrm{N} / \mathrm{O}$ case than in the $\mathrm{N}$ case, the Hispanic subgroup's consumption was $2.4 \%$ higher, and the majority subgroup's consumption was $1.8 \%$ higher.

The total electricity expenditure for the black subgroup in the N/O case was $0.3 \%$ lower in NES4 than in the status quo; for the Hispanic subgroup, there was no difference; and for the majority subgroup, it was $1.27 \%$ lower. The black subgroup spent $10.2 \%$ less than the majority subgroup and $0.6 \%$ more than the Hispanic subgroup, and the Hispanic subgroup spent $10.8 \%$ less than the majority subgroup. In the $\mathrm{N}$ case, the black and Hispanic subgroups each spent $11 \%$ less than the majority agent. Across cases, the black subgroup's expenditure was $2.7 \%$ higher in the N/O case than in the $\mathrm{N}$ case, the Hispanic agent's expenditure was $2.6 \%$ higher, and the majority agent's expenditure was $1.9 \%$ higher.

Total energy differences (see Table 10) between the N/O case and the reference case gave the black subgroup an $84 \%$ greater consumption than the majority subgroup and $21 \%$ greater than the Hispanic subgroup; the Hispanic subgroup was $52 \%$ higher than the majority subgroup. The expenditure difference for the black subgroup was $121.7 \%$ higher than that for the majority subgroup and $23.6 \%$ higher than that for the Hispanic subgroup; the difference for the Hispanic subgroup was 79.3\% higher than the majority.

For electric energy use, the differences across groups (see Table 11) for the NES4 scenario were even sharper. The black subgroup's difference in electricity consumption between the N/O case and the reference case was $213.9 \%$ higher than the majority subgroup's and 6\% higher than the Hispanic subgroup's. The Hispanic subgroup's difference in electricity consumption between the N/O case and the reference case was $196 \%$ higher than the majority's. The differences in electricity consumption between the N/O case and the reference case were $212 \%$ higher for the black subgroup than for the majority, $180 \%$ higher for the Hispanic subgroup, and $11.5 \%$ higher for the black subgroup vs. the Hispanic subgroup.

Trends in energy use are less pronounced with a lower assumed growth rate in new housing. The lower the new housing growth rate, the smaller is the fall in total energy consumption (see Table 12) and the rise in electricity consumption (see Table 13). In all cases, the majority's total energy consumption is projected to fall, and the majority's electricity consumption is projected to rise, by more than that of black or Hispanic households. The higher the new housing growth rates (i.e., NES6), the greater the differential rates of change between the majority and the two minority groups. 
TABLE 9 Electricity Consumption and Expenditures, NES4 Scenario, 4\% New Housing Growth

\begin{tabular}{|c|c|c|c|c|c|c|c|c|c|c|c|c|}
\hline \multirow[b]{3}{*}{ Year } & \multicolumn{6}{|c|}{$\begin{array}{l}\text { New House/Old House ESR Curve Sensitivity Based on Segment } c: \text { Population } \\
\text { Group in New or Old House }\end{array}$} & \multicolumn{6}{|c|}{ New House ESR Curve Sensitivity Applied Evenly to All Groups } \\
\hline & \multicolumn{2}{|c|}{ Majority } & \multicolumn{2}{|c|}{ Black } & \multicolumn{2}{|c|}{ Hispanic } & \multicolumn{2}{|c|}{ Majority } & \multicolumn{2}{|c|}{ Black } & \multicolumn{2}{|c|}{ Hispanic } \\
\hline & $\begin{array}{c}\text { Consump- } \\
\text { tion" }\end{array}$ & $\begin{array}{c}\text { Expendi- } \\
\text { ture }^{b}\end{array}$ & $\begin{array}{c}\text { Consump- } \\
\text { tion }\end{array}$ & $\begin{array}{l}\text { Expendi- } \\
\text { ture }\end{array}$ & $\begin{array}{c}\text { Consump- } \\
\text { tion }\end{array}$ & $\begin{array}{l}\text { Expendi- } \\
\text { ture }\end{array}$ & $\begin{array}{c}\text { Conoump- } \\
\text { tion }\end{array}$ & $\begin{array}{l}\text { Expendi- } \\
\text { ture }\end{array}$ & $\begin{array}{c}\text { Consump- } \\
\text { tion }\end{array}$ & $\begin{array}{c}\text { Expendi- } \\
\text { ture }\end{array}$ & $\begin{array}{c}\text { Consump- } \\
\text { tion }\end{array}$ & $\begin{array}{c}\text { Expendi- } \\
\text { ture }\end{array}$ \\
\hline 1987 & 31.5 & 758.1 & 27.3 & 695.8 & 26.1 & 705.5 & 31.5 & 757.3 & 27.3 & 694.9 & 26.1 & 704.5 \\
\hline 1989 & $\mathbf{3 3 . 0}$ & 712.0 & 28.6 & 651.0 & 26.6 & 645.1 & 32.8 & 708.6 & 28.4 & 647.1 & 26.4 & 641.0 \\
\hline 1991 & 33.4 & 708.4 & 29.4 & 661.3 & 27.1 & 648.2 & 33.0 & 699.0 & 29.0 & 650.5 & 26.7 & 637.9 \\
\hline 1993 & 34.0 & 724.8 & 29.1 & 659.5 & 27.2 & 654.4 & 33.1 & 706.7 & 28.2 & 637.6 & 26.4 & 635.3 \\
\hline 1995 & 33.7 & 764.7 & 29.1 & 699.6 & 27.8 & 704.6 & 32.5 & 736.9 & 27.7 & 664.6 & 26.5 & 671.6 \\
\hline 1997 & 34.1 & 849.2 & 29.2 & 772.8 & 26.4 & 745.2 & 32.8 & 815.1 & 27.6 & 728.8 & 25.0 & 704.6 \\
\hline 1999 & 35.1 & 894.9 & 30.5 & 828.6 & 27.5 & 797.3 & 33.8 & 860.8 & 28.9 & 783.7 & 26.1 & 755.0 \\
\hline 2001 & 34.6 & 871.9 & 28.8 & 771.8 & 27.4 & 771.9 & 33.6 & 844.6 & 27.5 & 735.4 & 26.4 & 740.0 \\
\hline 2003 & 33.6 & 824.0 & 27.2 & 711.6 & 26.3 & 733.5 & 32.9 & 807.2 & 26.4 & 688.3 & 25.5 & 711.3 \\
\hline 2005 & 34.2 & 816.5 & 27.3 & 695.9 & 25.9 & 699.9 & 33.9 & 808.4 & 26.9 & 684.6 & 25.4 & 683.6 \\
\hline 2007 & 35.1 & 812.0 & 28.0 & 690.0 & 26.2 & 687.4 & 35.0 & 809.4 & 27.9 & 686.4 & 26.0 & 683.3 \\
\hline 2009 & 36.2 & 842.5 & 28.8 & 713.9 & 26.9 & 710.7 & 36.2 & 844.1 & 28.9 & 718 & 27.0 & 713.4 \\
\hline Total Con- & 409 & & 343 & & 321 & & 401 & & 335 & & 314 & \\
\hline $\begin{array}{l}\text { sumption } \\
\text { Discounted } \\
\text { Expenditure }\end{array}$ & & 7,317 & & 6,564 & & 6,526 & & 7,178 & & 6,387 & & 6,356 \\
\hline
\end{tabular}

a $10^{6}$ Btulyr per househoid.

b \$yr per household. 
TABLE 10 Total Energy Consumption and Expenditures, Minus the Reference Case, NES4 Scenario, $4 \%$ New Housing Growth

\begin{tabular}{|c|c|c|c|c|c|c|c|c|c|c|c|c|}
\hline \multirow[b]{3}{*}{ Year } & \multicolumn{6}{|c|}{$\begin{array}{l}\text { New House/Old House ESR Curve Sensitivity Based on Segment of Population } \\
\text { Group in New or Old House }\end{array}$} & \multicolumn{6}{|c|}{ New House ESR Curve Sensitivity Applied Evenly to All Groups } \\
\hline & \multicolumn{2}{|c|}{ Majority } & \multicolumn{2}{|c|}{ Black } & \multicolumn{2}{|c|}{ Hispanic } & \multicolumn{2}{|c|}{ Majority } & \multicolumn{2}{|c|}{ Black } & \multicolumn{2}{|c|}{ Hispanic } \\
\hline & $\begin{array}{c}\text { Consump- } \\
\text { tion }\end{array}$ & $\begin{array}{l}\text { Expendi- } \\
\text { ture }\end{array}$ & $\begin{array}{c}\text { Consump- } \\
\text { tion }\end{array}$ & $\begin{array}{l}\text { Expendi- } \\
\text { ture }\end{array}$ & $\begin{array}{l}\text { Consump- } \\
\text { tion }\end{array}$ & $\begin{array}{c}\text { Expendi- } \\
\text { ture }\end{array}$ & $\begin{array}{c}\text { Consump- } \\
\text { tion }\end{array}$ & $\begin{array}{c}\text { Expendi- } \\
\text { ture }\end{array}$ & $\begin{array}{l}\text { Consump- } \\
\text { tion }\end{array}$ & $\begin{array}{l}\text { Expendi- } \\
\text { ture }\end{array}$ & $\begin{array}{l}\text { Consump- } \\
\text { tion }\end{array}$ & $\begin{array}{c}\text { Expendi- } \\
\text { ture }\end{array}$ \\
\hline 1987 & 0.00 & -0.05 & 0.00 & -0.02 & 0.00 & -0.03 & -0.20 & -0.18 & -0.18 & -0.18 & -0.12 & -0.18 \\
\hline 1989 & 0.68 & 0.57 & 0.71 & 0.70 & 0.66 & 0.64 & 0.10 & 0.02 & 0.09 & 0.06 & 0.11 & 0.02 \\
\hline 1991 & 0.99 & 0.97 & 1.35 & 1.30 & 1.15 & 1.18 & -0.59 & -0.53 & -0.54 & -0.52 & -0.58 & -0.51 \\
\hline 1993 & 1.20 & 1.05 & 1.89 & 1.82 & 1.48 & 1.36 & -1.90 & -1.81 & -1.80 & -1.80 & -1.93 & -1.86 \\
\hline 1995 & 1.32 & 1.03 & 2.40 & 2.26 & 1.96 & 1.87 & -3.14 & -3.09 & -3.23 & -3.15 & -3.11 & -3.11 \\
\hline 1997 & 1.56 & 1.09 & 2.93 & 2.73 & 2.26 & 2.17 & -3.65 & -3.66 & -3.78 & -3.74 & -3.68 & -3.67 \\
\hline 1999 & 1.59 & 1.20 & 2.95 & 2.79 & 2.35 & $\therefore .31$ & -3.50 & -3.51 & -3.71 & -3.56 & -3.65 & -3.52 \\
\hline 2001 & 1.28 & 0.97 & 2.78 & 2.62 & 2.26 & 2.02 & -2.57 & -2.81 & -3.07 & -2.92 & -2.97 & -2.92 \\
\hline 2003 & 0.65 & 0.49 & 1.95 & 1.73 & 1.81 & 1.26 & -2.37 & -2.14 & -2.43 & -2.21 & -2.42 & -2.26 \\
\hline 2005 & 0.33 & 0.16 & 1.16 & 0.88 & 0.84 & 0.71 & -1.53 & -1.33 & -1.45 & -1.39 & -1.80 & -1.39 \\
\hline 2007 & -0.11 & -0.15 & 0.20 & 0.20 & 0.48 & 0.42 & -0.89 & -0.71 & -0.79 & -0.67 & -0.84 & -0.77 \\
\hline 2009 & 0.11 & 0.04 & -0.10 & -0.07 & -0.25 & -0.23 & 0.00 & 0.09 & -0.10 & 0.00 & -0.25 & -0.05 \\
\hline Net Difference & 9.60 & 7.36 & 18.21 & 16.93 & 15.00 & 13.67 & -20.24 & -19.66 & -21.00 & -20.09 & -21.23 & -20.24 \\
\hline $\begin{array}{l}\text { Discounted } \\
\text { Difference }\end{array}$ & 7.59 & 5.90 & 14.02 & 13.08 & 11.54 & 10.58 & -15.20 & -14.82 & -15.73 & -15.12 & -15.82 & -15.21 \\
\hline
\end{tabular}


TABLE 11 Electricity Consumption and Expenditures, Minus the Reference Case, NES4 Scenario, 4\% New Housing Growth

\begin{tabular}{|c|c|c|c|c|c|c|c|c|c|c|c|c|}
\hline \multirow[b]{3}{*}{ Year } & \multicolumn{6}{|c|}{$\begin{array}{l}\text { New House/Old House ESR Curve Sensitivity Based on Segment of Population } \\
\text { Group in New or Old House }\end{array}$} & \multicolumn{6}{|c|}{ New House ESR Curve Sensitivity Applied Evenly to All Groups } \\
\hline & \multicolumn{2}{|c|}{ Majority } & \multicolumn{2}{|c|}{ Black } & \multicolumn{2}{|c|}{ Hispanic } & \multicolumn{2}{|c|}{ Majority } & \multicolumn{2}{|c|}{ Black } & \multicolumn{2}{|c|}{ Hispanic } \\
\hline & $\begin{array}{l}\text { Consump- } \\
\text { tion }\end{array}$ & $\begin{array}{l}\text { Expendi- } \\
\text { ture }\end{array}$ & $\begin{array}{l}\text { Consump- } \\
\text { tion }\end{array}$ & $\begin{array}{l}\text { Expendi- } \\
\text { ture }\end{array}$ & $\begin{array}{l}\text { Consump- } \\
\text { tion }\end{array}$ & $\begin{array}{l}\text { Expendi- } \\
\text { ture }\end{array}$ & $\begin{array}{c}\text { Consump- } \\
\text { tion }\end{array}$ & $\begin{array}{c}\text { Expendi- } \\
\text { ture }\end{array}$ & $\begin{array}{c}\text { Consump- } \\
\text { tion }\end{array}$ & $\begin{array}{c}\text { Expendi- } \\
\text { ture }\end{array}$ & $\begin{array}{c}\text { Consump- } \\
\text { tion }\end{array}$ & $\begin{array}{c}\text { Expendi- } \\
\text { ture }\end{array}$ \\
\hline 1987 & 0.00 & -0.05 & 0.00 & -0.03 & 0.00 & -0.04 & 0.00 & -0.16 & 0.00 & -0.16 & 0.00 & -0.18 \\
\hline 1989 & 0.61 & 0.54 & 0.70 & 0.66 & 0.76 & 0.62 & 0.30 & 0.06 & 0.00 & 0.06 & 0.00 & -0.02 \\
\hline 1991 & 0.60 & 0.85 & 1.03 & 1.15 & 0.74 & 1.11 & -0.60 & -0.48 & -0.34 & -0.50 & -0.74 & -0.50 \\
\hline 1993 & 0.89 & 0.74 & 1.39 & 1.56 & 1.12 & 1.08 & -1.78 & -1.78 & -1.74 & -1.82 & -1.86 & -1.87 \\
\hline 1995 & 0.30 & 0.50 & 1.39 & 1.83 & 1.46 & 1.63 & -3.27 & -3.15 & -3.48 & -3.26 & -3.28 & -3.13 \\
\hline 1997 & 0.29 & 0.45 & 1.74 & 2.13 & 1.93 & 1.91 & -3.53 & -3.58 & -3.83 & -3.69 & -3.47 & -3.64 \\
\hline 1999 & 0.29 & 0.54 & 2.01 & 2.20 & 1.85 & 2.11 & -3.43 & -3.29 & -3.34 & -3.34 & -3.33 & -3.30 \\
\hline 2001 & 0.29 & 0.44 & 1.77 & 2.04 & 1.48 & 1.54 & -2.61 & -2.71 & -2.83 & -2.78 & -2.22 & -2.66 \\
\hline 2003 & 0.30 & 0.18 & 0.74 & 1.12 & 1.15 & 1.26 & -1.79 & -1.86 & -2.22 & -2.17 & -1.92 & -1.81 \\
\hline 2005 & -0.29 & -0.17 & 0.37 & 0.39 & 0.39 & 0.65 & -1.17 & -1.16 & -1.10 & -1.24 & -1.55 & -1.70 \\
\hline 2007 & 0.00 & -0.16 & 0.00 & 0.03 & 0.00 & -0.03 & -0.28 & -0.48 & -0.36 & -0.49 & -0.76 & -0.63 \\
\hline 2009 & 0.00 & -0.01 & 0.00 & -0.17 & -0.37 & -0.22 & 0.00 & 0.18 & 0.35 & 0.41 & 0.00 & 0.15 \\
\hline Neí Difference & 3.28 & 3.84 & 11.15 & 12.91 & 10.51 & 11.62 & -18.16 & -18.43 & -18.91 & -18.99 & -19.15 & -19.27 \\
\hline $\begin{array}{l}\text { Discounted } \\
\text { Difference }\end{array}$ & 2.79 & 3.24 & 8.76 & 10.12 & 8.27 & 9.07 & -13.71 & -13.97 & -14.33 & -14.41 & -14.44 & -14.56 \\
\hline
\end{tabular}


TABLE 12 Total Energy Consumption Trends, NES4 Scenario, 4\% New Housing Growth (\% Change)

\begin{tabular}{|c|c|c|c|c|c|c|c|c|c|c|c|c|}
\hline \multirow[b]{3}{*}{ Year } & \multicolumn{6}{|c|}{$\begin{array}{l}\text { New House/Old House ESR Curve Sensitivity Based on Segment of Population } \\
\text { Group in New or Old House }\end{array}$} & \multicolumn{6}{|c|}{ New House ESR Curve Sensitivity Applied Evenly to All Groups } \\
\hline & \multicolumn{2}{|c|}{ Majority } & \multicolumn{2}{|c|}{ Black } & \multicolumn{2}{|c|}{ Hispanic } & \multicolumn{2}{|c|}{ Majority } & \multicolumn{2}{|c|}{ Black } & \multicolumn{2}{|c|}{ Hispanic } \\
\hline & $\begin{array}{c}\text { Consump- } \\
\text { tion }\end{array}$ & $\begin{array}{c}\text { Expendi- } \\
\text { ture }\end{array}$ & $\begin{array}{l}\text { Consump- } \\
\text { tion }\end{array}$ & $\begin{array}{l}\text { Expendi- } \\
\text { ture }\end{array}$ & $\begin{array}{l}\text { Consump- } \\
\text { tion }\end{array}$ & $\begin{array}{l}\text { Expendi- } \\
\text { ture }\end{array}$ & $\begin{array}{l}\text { Consump- } \\
\text { tion }\end{array}$ & $\begin{array}{l}\text { Expendi- } \\
\text { ture }\end{array}$ & $\begin{array}{l}\text { Consump- } \\
\text { tion }\end{array}$ & $\begin{array}{c}\text { Expendi- } \\
\text { ture }\end{array}$ & $\begin{array}{c}\text { Consump- } \\
\text { tion }\end{array}$ & $\begin{array}{c}\text { Expendi- } \\
\text { ture }\end{array}$ \\
\hline 1989 & 3.80 & -6.61 & 2.63 & -7.06 & 4.95 & -7.67 & 8.41 & -7.00 & 2.18 & $\begin{array}{r}-7.50 \\
3.15\end{array}$ & $\begin{array}{r}4.50 \\
-4.75\end{array}$ & $\begin{array}{r}-8.10 \\
0.00\end{array}$ \\
\hline $\begin{array}{l}1993 \\
1995\end{array}$ & $\begin{array}{l}-0.98 \\
-1.48\end{array}$ & $\begin{array}{l}0.69 \\
3.93\end{array}$ & $\begin{array}{r}0.18 \\
-1.95\end{array}$ & $\begin{array}{l}\mathbf{0 . 5 1} \\
\mathbf{3 . 3 5}\end{array}$ & $\begin{array}{r}1.59 \\
-0.67\end{array}$ & $\begin{array}{l}2.89 \\
4.39\end{array}$ & $\begin{array}{l}-2.48 \\
-2.85\end{array}$ & $\begin{array}{r}-0.70 \\
2.60\end{array}$ & -3.85 & 1.50 & -2.32 & $\begin{array}{l}1.31 \\
2.54\end{array}$ \\
\hline $\begin{array}{l}1995 \\
1997\end{array}$ & $\begin{array}{l}-1.48 \\
-2.40\end{array}$ & $\begin{array}{r}0.80 \\
10.89\end{array}$ & $\begin{array}{l}-1.90 \\
-1.89\end{array}$ & $\begin{array}{r}3.30 \\
11.68\end{array}$ & $\begin{array}{l}-0.67 \\
-2.82\end{array}$ & $\begin{array}{l}4.39 \\
9.97\end{array}$ & -3.14 & 10.16 & -2.96 & 10.38 & -3.68 & 9.02 \\
\hline 1999 & -1.74 & 10.10 & -0.64 & 13.52 & 1.05 & 13.74 & -1.62 & 10.16 & -0.59 & 13.66 & 0.99 & 13.75 \\
\hline 2001 & -1.25 & -7.62 & -0.74 & -8.81 & -1.03 & -8.45 & 0.00 & -6.74 & 0.10 & -8.05 & -0.24 & -7.62 \\
\hline 2003 & -1.37 & -10.48 & -2.33 & -13.95 & -2.21 & -12.11 & -0.55 & -9.43 & -0.89 & -12.57 & -1.22 & -10.85 \\
\hline 2005 & -1.61 & -1.38 & 0.00 & -0.56 & 0.00 & -1.50 & -0.44 & -0.25 & 1.79 & 1.11 & 1.61 & -0.08 \\
\hline 2007 & -1.85 & 3.30 & -3.34 & 4.15 & -1.07 & 4.65 & -0.78 & 4.28 & -1.76 & 5.63 & 0.24 & 5.61 \\
\hline 2009 & -2.66 & 6.04 & -2.57 & 8.47 & -3.36 & 5.81 & -2.01 & 6.68 & -1.60 & 9.49 & -2.07 & 7.27 \\
\hline $\begin{array}{l}\text { Discounted } \\
\text { Net \% Change }\end{array}$ & -8.22 & 7.03 & -6.72 & 10.92 & -3.96 & 8.84 & -9.17 & 6.62 & .7 .96 & 9.52 & -5.16 & 7.63 \\
\hline $\begin{array}{l}1987-2009 \\
\text { \% Change }\end{array}$ & -12.21 & 8.87 & -10.52 & 12.48 & -7.26 & 10.03 & -12.14 & 9.08 & -10.35 & 12.73 & -7.16 & 10.39 \\
\hline
\end{tabular}


TABLE 13 Electricity Consumption Trends, NES4 Scenario, 4\% New Housing Growth (\% Change)

\begin{tabular}{|c|c|c|c|c|c|c|c|c|c|c|c|c|}
\hline \multirow[b]{3}{*}{ Year } & \multicolumn{6}{|c|}{$\begin{array}{l}\text { New House/Old House ESR Curve Sensitivity Based on Segment of Population } \\
\text { Group in New or Old House }\end{array}$} & \multicolumn{6}{|c|}{ New House ESR Curve Sensitivity Applied Evenly to All Groups } \\
\hline & \multicolumn{2}{|c|}{ Majority } & \multicolumn{2}{|c|}{ Black } & \multicolumn{2}{|c|}{ Hispanic } & \multicolumn{2}{|c|}{ Majority } & \multicolumn{2}{|c|}{ Black } & \multicolumn{2}{|c|}{ Hispanic } \\
\hline & $\begin{array}{c}\text { Consump- } \\
\text { tion }\end{array}$ & $\begin{array}{l}\text { Expendi- } \\
\text { ture }\end{array}$ & $\begin{array}{c}\text { Consump- } \\
\text { tion }\end{array}$ & $\begin{array}{l}\text { Expendi- } \\
\text { ture }\end{array}$ & $\begin{array}{c}\text { Consump- } \\
\text { tion }\end{array}$ & $\begin{array}{l}\text { Expendi- } \\
\text { ture }\end{array}$ & $\begin{array}{c}\text { Consump- } \\
\text { tion }\end{array}$ & $\begin{array}{l}\text { Expendi- } \\
\text { ture }\end{array}$ & $\begin{array}{c}\text { Consump- } \\
\text { tion }\end{array}$ & $\begin{array}{l}\text { Expendi- } \\
\text { ture }\end{array}$ & $\begin{array}{l}\text { Consump- } \\
\text { tion }\end{array}$ & $\begin{array}{c}\text { Expendi- } \\
\text { ture }\end{array}$ \\
\hline 1989 & 4.76 & -6.08 & 4.76 & -6.44 & 1.92 & -8.56 & 4.44 & -6.43 & 4.03 & -6.88 & 1.15 & -9.01 \\
\hline 1991 & 1.21 & $-0 . \mathbf{6 1}$ & 2.80 & 1.58 & 1.88 & 0.48 & 0.30 & -1.35 & 2.11 & 0.53 & 1.14 & -0.48 \\
\hline 1993 & 1.80 & 2.32 & -1.02 & -0.27 & 0.37 & 0.96 & 0.30 & 1.10 & -2.76 & -1.98 & -1.12 & -0.41 \\
\hline 1995 & -0.88 & 6.50 & 0.00 & 6.08 & 2.21 & 7.67 & -1.81 & 4.27 & -1.77 & 4.23 & 0.38 & 5.71 \\
\hline 1997 & 1.19 & 11.05 & 0.34 & 10.46 & -5.04 & 6.76 & .92 & 10.61 & -0.36 & 9.66 & -5.66 & 4.91 \\
\hline 1999 & 2.93 & 5.38 & 4.45 & 7.22 & 4.17 & 6.99 & 3.05 & 5.61 & 4.71 & 7.53 & 4.40 & 7.15 \\
\hline 2001 & -1.42 & -2.57 & -5.57 & -6.85 & -0.36 & -3.19 & -0.59 & -1.88 & -4.84 & -6.16 & 1.15 & -1.99 \\
\hline 2003 & -2.89 & -5.49 & -5.56 & -7.81 & -4.01 & -4.97 & -2.08 & -4.43 & -4.00 & -6.40 & -3.41 & -3.88 \\
\hline 2005 & 1.79 & -0.91 & 0.37 & -2.19 & -1.52 & -4.58 & 3.04 & 0.15 & 1.89 & -0.54 & -0.39 & -3.89 \\
\hline 2007 & 2.63 & -0.55 & 2.56 & -0.85 & 1.16 & -1.79 & 3.24 & 0.12 & 3.72 & 0.26 & 2.36 & -0.04 \\
\hline 2009 & 3.13 & 3.76 & 2.86 & 3.46 & 2.67 & 3.39 & 3.43 & 4.29 & 3.58 & 4.60 & 3.85 & 4.41 \\
\hline $\begin{array}{l}\text { Discounted Net } \\
\text { \% Change }\end{array}$ & 11.15 & 8.61 & 5.53 & 3.57 & 3.14 & 1.43 & 10.33 & 7.87 & 4.56 & 2.63 & 2.24 & 0.47 \\
\hline $\begin{array}{l}1987-2009 \\
\text { \% Change }\end{array}$ & 14.92 & 11.13 & 5.49 & 2.60 & 3.07 & 0.74 & 14.92 & 11.46 & 5.86 & 3.32 & 3.45 & 1.26 \\
\hline
\end{tabular}




\section{RESULTS FROM THE 6\% NEW HOUSING GROWTH SCENARIO}

As predicted, for both the N/O and N cases, the NES6 total energy consumption and expenditures were lower than those of the status quo scenario (see Table 14). The total energy consumption for the black subgroup in the N/O case was $0.6 \%$ lower in NES6 than in the status quo case; for the Hispanic subgroup, it was $0.6 \%$ lower; and for the majority subgroup, it was $2 \%$ lower. The black subgroup consumed $14 \%$ more than the majority subgroup and $25 \%$ more than the Hispanic subgroup, and the majority subgroup consumed 9.8\% more than the Hispanic subgroup. In the $\mathrm{N}$ case, the black and Hispanic subgroups consumed $12 \%$ more and $9.7 \%$ less than the majority subgroup, respectively. Across cases, the black subgroup's consumption was $3.1 \%$ higher in the $N / O$ case than in the $N$ case, the Hispanic subgroup's consumption was $2.7 \%$ higher, and the majority subgroup's consumption was $1.8 \%$ higher.

The total energy expenditure for the black subgroup in the N/O case was $0.4 \%$ lower in NES6 than in the status quo case; for the Hispanic subgroup, it was $0.4 \%$ lower; and for the majority subgroup, it was $0.7 \%$ lower. The black subgroup spent $8.7 \%$ more than the majority subgroup and $1.1 \%$ more than the Hispanic subgroup, and the majority subgroup spent $6 \%$ more than the Hispanic subgroup. In the $\mathrm{N}$ case, the black and Hispanic subgroups spent $7.4 \%$ more and $6.5 \%$ less than the majority subgroup, respectively. Across cases, the black subgroup's expenditure was 3\% higher in the $\mathrm{N} / \mathrm{O}$ case than in the $\mathrm{N}$ case, the Hispanic subgroup's expenditure was $2.7 \%$ higher, and the majority subgroup's expenditure was $1.8 \%$ higher.

Electricity consumption for the black subgroup in N/O was $0.7 \%$ higher in NES6 than in the status quo case; for the Hispanic subgroup, it was $0.5 \%$ higher; and for the majority subgroup, it was $2.5 \%$ higher (see Table 15). The black subgroup consumed $17.7 \%$ less than the majority subgroup and $7.3 \%$ more than the Hispanic subgroup, and the majority subgroup consumed $30 \%$ more than the Hispanic subgroup. In the $\mathbf{N}$ case, the black and Hispanic subgroups consumed $17 \%$ and $23 \%$ less than the majority subgroup, respectively. Across cases, the black subgroup's consumption was $2.4 \%$ higher in the $\mathrm{N} / \mathrm{O}$ case than in the $\mathrm{N}$ case, the Hispanic subgroup's consumption was $2.2 \%$ higher, and the majority subgroup's consumption was $1.4 \%$ higher.

The total electricity expenditure for the black subgroup in the N/O case was 5\% higher in NES6 than in the status quo case; for the Hispanic subgroup, it was $0.2 \%$ higher; and for the majority subgroup, it was $2 \%$ higher. The black subgroup spent $12.3 \%$ less than the majority subgroup and $\mathbf{1 . 1 \%}$ more than the Hispanic subgroup; the Hispanic subgroup spent $13.4 \%$ less than the majority subgroup. In the $\mathrm{N}$ case, the black and Hispanic subgroups spent $13.4 \%$ and $14.2 \%$ less than the majority subgroup, respectively. Across cases, the black subgroup's expenditure was $2.6 \%$ higher in the N/O case than in the $\mathrm{N}$ case, the Hispanic subgroup's expenditure was $2.5 \%$ higher, and the majority subgroup's expenditure was $1.4 \%$ higher. 
TABLE 14 Total Energy Consumption and Expenditures, NES6 Scenario, 6\% New Housing Growth

\begin{tabular}{|c|c|c|c|c|c|c|c|c|c|c|c|c|}
\hline \multirow[b]{3}{*}{ Year } & \multicolumn{6}{|c|}{$\begin{array}{l}\text { New House/Old House ESR Curve Sensitivity Based on Segment of Population } \\
\text { Group in New or Old House }\end{array}$} & \multicolumn{6}{|c|}{ New House ESR Curve Sensitivity Applied Evenly to All Groups } \\
\hline & \multicolumn{2}{|c|}{ Majority } & \multicolumn{2}{|c|}{ Black } & \multicolumn{2}{|c|}{ Hispanic } & \multicolumn{2}{|c|}{ Majority } & \multicolumn{2}{|c|}{ Black } & \multicolumn{2}{|c|}{ Hispanic } \\
\hline & $\begin{array}{c}\text { Consump- } \\
\text { tion }\end{array}$ & $\begin{array}{c}\text { Expendi- } \\
\text { ture }^{b}\end{array}$ & $\begin{array}{c}\text { Consump- } \\
\text { tion }\end{array}$ & $\begin{array}{l}\text { Expendi- } \\
\text { ture }\end{array}$ & $\begin{array}{c}\text { Consump- } \\
\text { tion }\end{array}$ & $\begin{array}{c}\text { Expendi- } \\
\text { ture }\end{array}$ & $\begin{array}{l}\text { Consump- } \\
\text { tion }\end{array}$ & $\begin{array}{l}\text { Expendi- } \\
\text { ture }\end{array}$ & $\begin{array}{l}\text { Consump- } \\
\text { tion }\end{array}$ & $\begin{array}{l}\text { Expendi- } \\
\text { ture }\end{array}$ & $\begin{array}{l}\text { Consump- } \\
\text { tion }\end{array}$ & $\begin{array}{l}\text { Expendi- } \\
\text { ture }\end{array}$ \\
\hline 1987 & 99.9 & $1,268.8$ & 110.3 & $1,354.6$ & 86.8 & $1,189.4$ & 99.7 & $1,267.1$ & 110.1 & $1,352.4$ & 86.7 & $1,187.6$ \\
\hline 1989 & 103.1 & $1,183.5$ & 113.1 & $1,257.7$ & 90.9 & $1,096.6$ & 102.5 & $1,177.3$ & 112.3 & $1,249.7$ & 90.4 & $1,089.9$ \\
\hline 1991 & 101.2 & $1,205.6$ & 112.5 & $1,310.9$ & 87.3 & $1,104.9$ & 99.7 & $1,188.9$ & 110.4 & $1,287.3$ & 85.8 & $1,086.8$ \\
\hline 1993 & 99.3 & $1,210.3$ & 112.4 & $1,314.8$ & 88.5 & $1,137.3$ & 96.5 & $1,179.3$ & 108.3 & $1,268.7$ & 85.7 & $1,102.2$ \\
\hline 1995 & 96.9 & $1,253.3$ & 109.9 & $1,355.7$ & 87.7 & $1,183.8$ & 93.2 & $1,209.2$ & 104.0 & $1,285.8$ & 83.5 & $1,128.5$ \\
\hline 1997 & 93.5 & $1,379.8$ & 107.4 & $1,508.3$ & 84.6 & $1,294.4$ & 89.5 & $1,326.6$ & 100.6 & $1,416.0$ & 79.9 & $1,224.5$ \\
\hline 1999 & 91.1 & $1,507.1$ & 106.4 & $1,707.5$ & 85.4 & $1,468.3$ & 87.4 & $1,452.9$ & 99.8 & $1,606.0$ & 80.7 & $1,390.0$ \\
\hline $\begin{array}{l}2001 \\
2003\end{array}$ & 89.3 & $1,396.0$ & 105.4 & $1,556.4$ & 84.3 & $1,346.1$ & 86.5 & $1,358.5$ & 99.7 & $1,476.5$ & 80.2 & $1,286.5$ \\
\hline $\begin{array}{l}2003 \\
2005\end{array}$ & 87.3 & $1,257.1$ & 102.3 & $1,336.6$ & 82.2 & $1,183.1$ & 85.4 & $1,235.4$ & 98.2 & $1,287.9$ & 79.1 & $1,146.1$ \\
\hline $\begin{array}{l}2005 \\
2007\end{array}$ & 85.7 & $1,240.2$ & 102.3 & $1,327.9$ & 82.1 & $1,166.2$ & 84.7 & $1,229.0$ & 99.8 & $1,300.0$ & 80.3 & $1,144.9$ \\
\hline $\begin{array}{l}2007 \\
2009\end{array}$ & 84.1 & $1,277.3$ & 98.5 & $1,375.4$ & 81.0 & $1,216.9$ & 83.8 & $1,273.4$ & 97.6 & $1,364.4$ & 80.1 & $1,204.4$ \\
\hline 2009 & 81.3 & $1,339.3$ & 95.4 & $1,482.1$ & 77.8 & $1,272.9$ & 81.3 & $1,339.7$ & 95.4 & $1,483.0$ & 77.9 & $1,274.8$ \\
\hline $\begin{array}{l}\text { Total Con- } \\
\text { sumption }\end{array}$ & 1,113 & & 1,276 & & 1,019 & & 1,090 & & 1,236 & & 990 & \\
\hline $\begin{array}{l}\text { Discounted } \\
\text { Expenditure }\end{array}$ & & 11,909 & & 12,947 & & 11,234 & & 11,692 & & 12,559 & & 10,935 \\
\hline
\end{tabular}

- $10^{6} \mathrm{Btu} / \mathrm{yr}$ per household.

b \$yr per household. 
TABLE 15 Electricity Consumption and Expenditures, NES6 Scenario, 6\% New Housing Growth

\begin{tabular}{|c|c|c|c|c|c|c|c|c|c|c|c|c|}
\hline \multirow[b]{3}{*}{ Year } & \multicolumn{6}{|c|}{$\begin{array}{l}\text { New House/Old House ESR Curve Sensitivity Based on Segment of Population } \\
\text { Group in New or Old House }\end{array}$} & \multicolumn{6}{|c|}{ New House ESR Curve Sensitivity Applied Evenly to All Groups } \\
\hline & \multicolumn{2}{|c|}{ Majority } & \multicolumn{2}{|c|}{ Black } & \multicolumn{2}{|c|}{ Hispanic } & \multicolumn{2}{|c|}{ Majority } & \multicolumn{2}{|c|}{ Black } & \multicolumn{2}{|c|}{ Hispanic } \\
\hline & $\begin{array}{l}\text { Consump- } \\
\text { tion" }\end{array}$ & $\begin{array}{c}\text { Expendi- } \\
\text { ture }^{b}\end{array}$ & $\begin{array}{c}\text { Consump- } \\
\text { tion }\end{array}$ & $\begin{array}{c}\text { Expendi- } \\
\text { ture }\end{array}$ & $\begin{array}{c}\text { Consump- } \\
\text { tion }\end{array}$ & $\begin{array}{c}\text { Expendi- } \\
\text { ture }\end{array}$ & $\begin{array}{c}\text { Consump- } \\
\text { tion }\end{array}$ & $\begin{array}{c}\text { Expendi- } \\
\text { ture }\end{array}$ & $\begin{array}{c}\text { Consump- } \\
\text { tion }\end{array}$ & $\begin{array}{c}\text { Expendi- } \\
\text { ture }\end{array}$ & $\begin{array}{c}\text { Consump- } \\
\text { tion }\end{array}$ & $\begin{array}{c}\text { Expendi- } \\
\text { ture }\end{array}$ \\
\hline 1987 & 31.5 & 758.1 & 27.3 & 695.8 & 26.1 & 705.5 & 31.5 & 757.3 & 27.3 & 694.9 & 26.1 & 704.5 \\
\hline 1989 & 33.3 & 716.3 & 28.6 & 651.7 & 26.6 & 645.4 & 33.1 & 713.1 & 28.4 & 647.8 & 26.4 & 641.3 \\
\hline 1991 & $\mathbf{3 4 . 0}$ & 716.9 & 29.6 & 663.5 & 27.2 & 647.8 & 33.5 & 708.1 & 29.1 & 652.8 & 26.8 & 637.7 \\
\hline 1993 & 34.8 & 738.2 & 29.3 & 662.1 & 27.4 & 656.9 & 34.0 & 722.0 & 28.4 & 640.7 & 26.6 & 638.6 \\
\hline 1995 & 34.7 & 781.7 & 29.4 & 703.1 & 27.9 & 705.9 & 33.7 & 758.1 & 28.0 & 669.1 & 26.7 & 674.5 \\
\hline 1997 & $\mathbf{3 5 . 3}$ & 871.9 & 29.5 & 775.9 & 26.4 & 743.0 & 34.2 & 844.5 & 27.9 & 733.6 & 25.1 & 705.2 \\
\hline 1999 & 36.6 & 923.2 & 30.9 & 835.8 & 27.6 & 795.5 & 35.6 & 897.5 & 29.4 & 793.2 & 26.4 & 756.6 \\
\hline 2001 & 36.6 & 909.8 & 29.3 & 781.3 & 27.8 & 775.5 & 35.9 & 890.6 & 28.1 & 747.1 & 26.8 & 746.7 \\
\hline 2003 & 35.8 & 868.7 & 27.7 & 719.3 & 26.5 & 734.2 & 35.4 & 857.8 & 27.0 & 697.9 & 25.8 & 714.5 \\
\hline 2005 & 36.8 & 866.3 & 28.0 & 707.8 & 26.4 & 706.5 & 36.7 & 861.6 & 27.6 & 697.4 & 25.9 & 692.3 \\
\hline 2007 & 38.2 & 870.6 & 28.8 & 703.5 & 26.9 & 699.0 & 38.1 & 869.2 & 28.7 & 700.3 & 26.8 & 695.5 \\
\hline 2009 & 39.4 & 903.8 & 29.7 & 728.2 & 27.3 & 711.5 & 39.5 & 904.6 & 29.8 & 731.9 & 27.4 & 713.8 \\
\hline Total Con- & 427 & & 348 & & 324 & & 421 & & 340 & & 317 & \\
\hline $\begin{array}{l}\text { sumption } \\
\text { Discounted } \\
\text { Expenditure }\end{array}$ & & 7,552 & & 6,616 & & 6,540 & & 7,442 & & 6,446 & & 6,383 \\
\hline
\end{tabular}

a $10^{6} \mathrm{Btw} / \mathrm{yr}$ per household.

b $\$ / y r$ per household. 
Total energy differences between the N/O case and the reference case gave the black subgroup a sizeable $343 \%$ greater consumption difference compared with the majority and a 36\% greater difference than the Hispanic subgroup (see Table 16). The difference for the Hispanic subgroup, at $225 \%$, was significantly higher than that for the majority. The expenditure difference for the black subgroup was $890 \%$ higher than the majority and $37 \%$ higher than the Hispanic subgroup. The difference for the Hispanic subgroup was $623 \%$ higher than that for the majority.

For electric energy use, it is hard to gauge the differences across groups for the NES6 scenario, because the majority saved electricity in the N/O case relative to the reference case, and the two minority subgroups used more (see Table 17). The black subgroup's difference between the N/O case and reference case was roughly $600 \%$ higher than the majority's and 7\% higher than the Hispanic subgroup's. The Hispanic subgroup's difference between the $\mathrm{N} / \mathrm{O}$ case and the reference case electricity consumption was roughly $450 \%$ higher than the majority's. The differences between the N/O case electricity expenditure and that in the reference case are hard to gauge for the same reason. They were roughly $660 \%$ higher for the black subgroup than for the majority, roughly $530 \%$ higher for the Hispanic subgroup, and $21.5 \%$ higher for the black subgroups vs. the Hispanic subgroup.

Trends in energy use are more pronounced with a higher assumed growth rate in new housing. The higher the new housing growth rate, the bigger the fall in total energy consumption (Table 18) and the rise in electricity consumption (Table 19). In all cases, the majority's total energy consumption is projected to fall, and the majority's electricity consumption is projected to rise, by more than that of black or Hispanic households. The higher the new housing growth rates (i.e., NES6) go, the greater the differential rates of change between the majority and the two minority groups become.

Relative rankings of minority groups in each ESR market penetration case and for each housing growth scenario are summarized in Table 20. 
TABLE 16 Total Energy Consumption and Expenditures, Minus the Reference Case, NES6 Scenario, 6\% New Housing Growth

\begin{tabular}{|c|c|c|c|c|c|c|c|c|c|c|c|c|}
\hline \multirow[b]{3}{*}{ Year } & \multicolumn{6}{|c|}{$\begin{array}{l}\text { New House/Old House ESR Curve Sensitivity Based on Segment of Population } \\
\text { Group in New or Old House }\end{array}$} & \multicolumn{6}{|c|}{ New House ESR Curve Sensitivity Applied Evenly to All Groups } \\
\hline & \multicolumn{2}{|c|}{ Majority } & \multicolumn{2}{|c|}{ Black } & \multicolumn{2}{|c|}{ Hispanic } & \multicolumn{2}{|c|}{ Majority } & \multicolumn{2}{|c|}{ Black } & \multicolumn{2}{|c|}{ Hispanic } \\
\hline & $\begin{array}{l}\text { Consump- } \\
\text { tion }\end{array}$ & $\begin{array}{l}\text { Expendi- } \\
\text { ture }\end{array}$ & $\begin{array}{c}\text { Consump- } \\
\text { tion }\end{array}$ & $\begin{array}{c}\text { Expendi- } \\
\text { ture }\end{array}$ & $\begin{array}{l}\text { Consump- } \\
\text { tion }\end{array}$ & $\begin{array}{c}\text { Expendi- } \\
\text { ture }\end{array}$ & $\begin{array}{l}\text { Consump- } \\
\text { tion }\end{array}$ & $\begin{array}{c}\text { Expendi- } \\
\text { ture }\end{array}$ & $\begin{array}{l}\text { Consump- } \\
\text { tion }\end{array}$ & $\begin{array}{c}\text { Expendi- } \\
\text { ture }\end{array}$ & $\begin{array}{l}\text { Consump- } \\
\text { tion }\end{array}$ & $\begin{array}{c}\text { Expendi- } \\
\text { ture }\end{array}$ \\
\hline 1987 & 0.00 & -0.05 & 0.00 & -0.02 & 0.00 & -0.03 & -0.20 & -0.18 & -0.18 & -0.18 & -0.12 & -0.18 \\
\hline 1989 & 0.59 & 0.55 & 0.71 & 0.70 & 0.55 & 0.64 & 0.00 & 0.03 & 0.00 & 0.06 & 0.00 & 0.03 \\
\hline 1991 & 1.00 & 0.88 & 1.35 & 1.28 & 1.16 & 1.14 & -0.50 & -0.52 & -0.54 & -0.54 & -0.58 & -0.52 \\
\hline 1993 & 1.02 & 0.77 & 1.90 & 1.76 & 1.37 & 1.26 & -1.83 & -1.81 & -1.81 & -1.81 & -1.83 & -1.86 \\
\hline 1995 & 0.73 & 0.44 & 2.33 & 2.12 & 1.74 & 1.65 & -3.12 & -3.09 & -3.17 & -3.14 & -3.13 & -3.10 \\
\hline 1997 & 0.65 & 0.20 & 2.68 & 2.52 & 1.93 & 1.83 & -3.66 & -3.67 & -3.82 & -3.75 & -3.73 & -3.67 \\
\hline 1999 & 0.44 & 0.10 & 2.70 & 2.54 & 2.03 & 1.92 & -3.64 & -3.50 & -3.67 & -3.56 & -3.58 & -3.52 \\
\hline 2001 & 0.22 & -0.14 & 2.53 & 2.35 & 1.81 & 1.58 & -2.92 & -2.82 & -3.02 & -2.91 & -3.14 & -2.91 \\
\hline 2003 & -0.23 & -0.43 & 1.59 & 1.47 & 1.36 & 0.90 & -2.40 & -2.15 & -2.48 & -2.23 & -2.47 & -2.25 \\
\hline 2005 & -0.23 & -0.43 & 0.99 & 0.74 & 0.49 & 0.45 & -1.40 & -1.32 & -1.48 & -1.38 & -1.71 & -1.39 \\
\hline 2007 & -0.47 & -0.42 & 0.20 & 0.14 & 0.37 & 0.27 & -0.83 & -0.73 & -0.71 & -0.66 & -0.74 & -0.76 \\
\hline 2009 & 0.12 & 0.08 & 0.00 & -0.05 & -0.38 & -0.26 & 0.12 & 0.11 & 0.00 & 0.01 & -0.26 & -0.11 \\
\hline Net Difference & 3.83 & 1.57 & 16.98 & 15.55 & 12.43 & 11.35 & -20.37 & -19.64 & -20.88 & -20.09 & -21.30 & -20.25 \\
\hline $\begin{array}{l}\text { Discounted } \\
\text { Difference }\end{array}$ & 3.40 & 1.67 & 13.13 & 12.07 & 9.69 & 8.91 & -15.31 & -14.81 & -15.68 & -15.12 & -15.90 & -15.21 \\
\hline
\end{tabular}


TABLE 17 Electricity Consumption and Expenditures, Minus the Reference Case, NES6 Scenario, 6\% New Housing Growth

\begin{tabular}{|c|c|c|c|c|c|c|c|c|c|c|c|c|}
\hline \multirow[b]{3}{*}{ Year } & \multicolumn{6}{|c|}{$\begin{array}{l}\text { New House/Old House ESR Curve Sensitivity Based on Segment of Population } \\
\text { Group in New or Old House }\end{array}$} & \multicolumn{6}{|c|}{ New House ESR Curve Seissitivity Applied Evenly to All Groups } \\
\hline & \multicolumn{2}{|c|}{ Majority } & \multicolumn{2}{|c|}{ Black } & \multicolumn{2}{|c|}{ Hispanic } & \multicolumn{2}{|c|}{ Majority } & \multicolumn{2}{|c|}{ Black } & \multicolumn{2}{|c|}{ Hispanic } \\
\hline & $\begin{array}{l}\text { Consump- } \\
\text { tion }\end{array}$ & $\begin{array}{l}\text { Expendi- } \\
\text { ture }\end{array}$ & $\begin{array}{l}\text { Consump- } \\
\text { tion }\end{array}$ & $\begin{array}{l}\text { Expendi- } \\
\text { ture }\end{array}$ & $\begin{array}{l}\text { Consump- } \\
\text { tion }\end{array}$ & $\begin{array}{l}\text { Expendi- } \\
\text { ture }\end{array}$ & $\begin{array}{c}\text { Consump- } \\
\text { tion }\end{array}$ & $\begin{array}{l}\text { Expendi- } \\
\text { ture }\end{array}$ & $\begin{array}{c}\text { Consump- } \\
\text { tion }\end{array}$ & $\begin{array}{l}\text { Expendi- } \\
\text { ture }\end{array}$ & $\begin{array}{c}\text { Consump- } \\
\text { tion }\end{array}$ & $\begin{array}{l}\text { Expendi- } \\
\text { ture }\end{array}$ \\
\hline 1987 & 0.00 & -0.05 & 0.00 & -0.03 & 0.00 & -0.04 & 0.00 & -0.16 & 0.00 & -0.16 & 0.00 & -0.18 \\
\hline 1989 & 0.60 & 0.51 & 0.70 & 0.66 & 0.76 & 0.64 & 0.00 & 0.06 & 0.00 & 0.06 & 0.00 & -0.02 \\
\hline 1991 & 0.89 & 0.76 & 1.02 & 1.13 & 1.12 & 1.06 & -0.59 & -0.48 & -0.68 & -0.50 & -0.37 & -0.51 \\
\hline 1993 & 0.58 & 0.42 & 1.38 & 1.47 & 1.11 & 0.97 & -1.73 & -1.78 & -1.73 & -1.81 & -1.85 & -1.84 \\
\hline 1995 & -0.29 & -0.13 & 1.73 & 1.66 & 1.09 & 1.39 & -3.16 & -3.14 & -3.11 & -3.25 & -3.26 & $-\mathbf{3 . 1 2}$ \\
\hline 1997 & -0.56 & -0.46 & 1.72 & 1.85 & 1.54 & 1.53 & -3.66 & -3.58 & -3.79 & -3.70 & -3.46 & -3.63 \\
\hline 1999 & -0.54 & -0.54 & 1.64 & 1.85 & 1.47 & 1.65 & -3.26 & -3.31 & -3.29 & -3.34 & -2.94 & -3.32 \\
\hline 2001 & -0.81 & -0.63 & 1.38 & 1.71 & 1.09 & 1.06 & -2.71 & -2.73 &. .77 & -2.75 & -2.55 & -2.70 \\
\hline 2003 & -0.83 & -0.64 & 0.36 & 0.83 & 0.76 & 0.87 & -1.94 & -1.89 & -2.17 & -2.17 & -1.90 & -1.84 \\
\hline 2005 & -0.81 & -0.69 & 0.00 & 0.24 & 0.38 & 0.36 & -1.08 & -1.23 & -1.43 & -1.23 & -1.52 & -1.66 \\
\hline 2007 & -0.26 & -0.33 & -0.35 & -0.01 & -0.37 & -0.13 & -0.52 & -0.49 & -0.69 & -0.47 & -0.74 & -0.63 \\
\hline 2009 & 0.00 & 0.04 & 0.00 & -0.12 & 0.00 & -0.10 & 0.25 & 0.13 & 0.34 & 0.38 & 0.37 & 0.22 \\
\hline Net Difference & -2.04 & -1.74 & 9.61 & 11.24 & 8.94 & 9.25 & -18.41 & -18.60 & -19.34 & -18.94 & -18.22 & -19.22 \\
\hline $\begin{array}{l}\text { Discounted } \\
\text { Difference }\end{array}$ & -1.00 & -0.87 & 7.77 & 8.89 & 7.16 & 7.33 & -13.95 & -14.08 & -14.59 & -14.37 & -13.74 & -14.53 \\
\hline
\end{tabular}


TABLE 18 Total Energy Consumption Trends, NES6 Scenario, 6\% New Housing Growth (\% Change)

\begin{tabular}{|c|c|c|c|c|c|c|c|c|c|c|c|c|}
\hline \multirow[b]{3}{*}{ Year } & \multicolumn{6}{|c|}{$\begin{array}{l}\text { New House/Old House ESR Curve Sensitivity Baned on Segment of Population } \\
\text { Group in New or Old House }\end{array}$} & \multicolumn{6}{|c|}{ New House ESR Curve Sensitivity Applied Evenly to All Groups } \\
\hline & \multicolumn{2}{|c|}{ Majority } & \multicolumn{2}{|c|}{ Black } & \multicolumn{2}{|c|}{ Hiepanic } & \multicolumn{2}{|c|}{ Majority } & \multicolumn{2}{|c|}{ Black } & \multicolumn{2}{|c|}{ Hiopanic } \\
\hline & $\begin{array}{c}\text { Consump- } \\
\text { tion }\end{array}$ & $\begin{array}{l}\text { Expendi- } \\
\text { ture }\end{array}$ & $\begin{array}{l}\text { Consump- } \\
\text { tion }\end{array}$ & $\begin{array}{l}\text { Expendi- } \\
\text { ture }\end{array}$ & $\begin{array}{c}\text { Consump- } \\
\text { tion }\end{array}$ & $\begin{array}{c}\text { Expendi- } \\
\text { ture }\end{array}$ & $\begin{array}{c}\text { Consump- } \\
\text { tion }\end{array}$ & $\begin{array}{c}\text { Expendi- } \\
\text { ture }\end{array}$ & $\begin{array}{l}\text { Consump- } \\
\text { tion }\end{array}$ & $\begin{array}{c}\text { Expendi- } \\
\text { ture }\end{array}$ & $\begin{array}{c}\text { Consump- } \\
\text { tion }\end{array}$ & $\begin{array}{l}\text { Expendi- } \\
\text { ture }\end{array}$ \\
\hline 1989 & 3.20 & -6.72 & 2.54 & -7.15 & 4.72 & -7.80 & 2.81 & -7.09 & 2.00 & -7.59 & 4.27 & -8.23 \\
\hline 1991 & -1.84 & 1.87 & -0.53 & 4.23 & -3.96 & 0.76 & -2.73 & 0.99 & -1.69 & 3.01 & -5.09 & -0.28 \\
\hline 1993 & -1.88 & 0.39 & -0.09 & 0.30 & 1.37 & 2.93 & -3.21 & -0.81 & -1.90 & -1.44 & -0.12 & 1.42 \\
\hline 1995 & -2.42 & 3.55 & -2.22 & 3.11 & -0.90 & 4.09 & -3.42 & 2.54 & -3.97 & 1.35 & -2.57 & 2.39 \\
\hline 1997 & -3.51 & 10.09 & -2.27 & 11.26 & -3.53 & 9.34 & -3.97 & 9.71 & -3.27 & 10.13 & -4.31 & 8.51 \\
\hline 1999 & -2.57 & 9.23 & -0.93 & 13.21 & 0.95 & 13.43 & -2.35 & 9.52 & -0.80 & 13.42 & 1.00 & 13.52 \\
\hline 2001 & -1.98 & -7.37 & -0.94 & -8.85 & -1.29 & -8.32 & -1.03 & -6.50 & -0.10 & -8.06 & -0.62 & -7.45 \\
\hline 2003 & -2.24 & -9.95 & -2.94 & -14.12 & -2.49 & -12.11 & -1.27 & -9.06 & -1.50 & -12.77 & -1.37 & -10.91 \\
\hline 2005 & -1.83 & -1.31 & 0.00 & -0.65 & -0.12 & -1.43 & -0.82 & -0.52 & 1.63 & 0.94 & 1.52 & -0.10 \\
\hline 2007 & -1.87 & 2.99 & -3.71 & 3.58 & -1.34 & 4.35 & -1.06 & 3.61 & -2.20 & 4.95 & -0.25 & 5.20 \\
\hline 2009 & -3.33 & 4.85 & -3.15 & 7.76 & -3.95 & 4.60 & -2.98 & 5.21 & -2.25 & 8.69 & -2.75 & 5.85 \\
\hline $\begin{array}{l}\text { Discounted Net } \\
\text { \% Change }\end{array}$ & -13.96 & 5.13 & -9.13 & 8.90 & -6.45 & 6.76 & -14.66 & 4.36 & -10.33 & 7.56 & -7.49 & 5.62 \\
\hline $\begin{array}{l}\text { 1987-2009 } \\
\text { \% Change }\end{array}$ & -18.62 & 5.56 & -13.51 & 9.41 & -10.36 & 7.02 & -18.45 & 5.73 & -13.35 & 9.66 & -10.15 & 7.34 \\
\hline
\end{tabular}


TABLE 19 Electricity Consumption Trends, NES6 Scenario, $6 \%$ New Housing Growth (\% Change)

\begin{tabular}{|c|c|c|c|c|c|c|c|c|c|c|c|c|}
\hline \multirow[b]{3}{*}{ Year } & \multicolumn{6}{|c|}{$\begin{array}{l}\text { New House/Old House ESR Curve Sensitivity Based on Segment of Population } \\
\text { Group in New or Old House }\end{array}$} & \multicolumn{6}{|c|}{ New House ESR Curve Sensitivity Applied Evenly to All Groups } \\
\hline & \multicolumn{2}{|c|}{ Majority } & \multicolumn{2}{|c|}{ Black } & \multicolumn{2}{|c|}{ Hispanic } & \multicolumn{2}{|c|}{ Majority } & \multicolumn{2}{|c|}{ Black } & \multicolumn{2}{|c|}{ Hispanic } \\
\hline & $\begin{array}{l}\text { Consump- } \\
\text { tion }\end{array}$ & $\begin{array}{l}\text { Expendi- } \\
\text { ture }\end{array}$ & $\begin{array}{l}\text { Consump- } \\
\text { tion }\end{array}$ & $\begin{array}{l}\text { Expendi- } \\
\text { ture }\end{array}$ & $\begin{array}{l}\text { Consump- } \\
\text { tion }\end{array}$ & $\begin{array}{c}\text { Expendi- } \\
\text { ture }\end{array}$ & $\begin{array}{c}\text { Consump- } \\
\text { tion }\end{array}$ & $\begin{array}{l}\text { Expendi- } \\
\text { ture }\end{array}$ & $\begin{array}{c}\text { Consump- } \\
\text { tion }\end{array}$ & $\begin{array}{l}\text { Expendi- } \\
\text { ture }\end{array}$ & $\begin{array}{c}\text { Consump- } \\
\text { tion }\end{array}$ & $\begin{array}{l}\text { Expendi- } \\
\text { ture }\end{array}$ \\
\hline 1989 & 6.71 & -5.51 & 4.76 & -6.34 & 1.92 & -8.62 & 5.08 & -5.84 & 4.03 & -6.78 & 1.15 & -8.97 \\
\hline 1991 & 2.10 & 0.08 & 3.50 & 1.81 & 2.26 & 0.37 & 1.21 & -0.70 & 2.46 & 0.77 & 1.52 & -0.56 \\
\hline 1993 & 2.35 & 2.97 & -1.01 & -0.21 & 0.74 & 1.40 & 1.49 & 1.96 & -2.41 & -1.85 & -0.75 & 0.14 \\
\hline 1995 & -0.29 & 5.89 & 0.34 & 6.19 & 1.82 & 7.46 & -0.88 & 5.00 & -1.41 & 4.43 & 0.38 & 5.62 \\
\hline 1997 & 1.73 & 11.54 & 0.34 & 10.35 & -5.38 & 5.26 & 1.48 & 11.40 & -0.36 & 9.64 & -5.99 & 4.55 \\
\hline 1999 & 3.68 & 5.88 & 4.75 & 7.72 & 4.65 & 7.07 & 4.09 & 6.28 & 5.38 & 8.12 & 5.18 & 7.29 \\
\hline 2001 & 0.00 & -1.45 & -5.18 & -6.52 & 0.72 & -2.51 & 0.84 & -0.77 & -4.42 & -5.81 & 1.52 & -1.31 \\
\hline 2003 & -2.19 & -4.52 & -5.46 & -7.94 & -4.68 & -5.33 & -1.39 & -3.68 & -3.91 & -6.59 & -3.73 & -4.31 \\
\hline 2005 & 2.79 & -0.28 & 1.08 & -1.60 & -0.38 & -3.77 & 3.67 & 0.44 & 2.22 & -0.07 & 0.39 & -3.11 \\
\hline 2007 & 3.80 & -0.50 & 2.86 & -0.61 & 1.89 & -1.06 & 3.81 & 0.88 & 3.99 & 0.42 & 3.47 & 0.46 \\
\hline 2009 & 3.14 & 3.81 & 3.13 & 3.51 & 1.49 & 1.79 & 3.67 & 4.07 & 3.83 & 4.51 & 2.24 & 2.63 \\
\hline $\begin{array}{l}\text { Discounted } \\
\text { Net \% Change }\end{array}$ & 17.64 & 13.83 & 7.80 & 5.00 & 4.31 & 1.52 & 17.11 & 13.28 & 6.85 & 4.11 & 3.51 & 0.63 \\
\hline $\begin{array}{l}\text { 1987-2009 } \\
\text { \% Change }\end{array}$ & 25.08 & 19.22 & 8.79 & 4.66 & 4.60 & .85 & 25.40 & 19.45 & 9.16 & 5.32 & 4.98 & 1.32 \\
\hline
\end{tabular}


TABLE 20 Relative Rankings of Minority Groups in Each ESR Market Penetration Case and in Each Housing Growth Scenario ${ }^{\text {a }}$

\begin{tabular}{|c|c|c|c|}
\hline Scenario & $\begin{array}{c}\text { Reference } \\
\text { Case }\end{array}$ & $\begin{array}{c}\text { New House/ } \\
\text { Old House } \\
\text { Case }\end{array}$ & $\begin{array}{c}\text { New } \\
\text { House } \\
\text { Case }\end{array}$ \\
\hline $\begin{array}{l}\text { Status Quo } \\
\text { Total energy consumption } \\
\text { Total energy expenditure } \\
\text { Electricity consumption } \\
\text { Electricity expenditure }\end{array}$ & $\begin{array}{l}\mathrm{B}, \mathrm{M}, \mathrm{H} \\
\mathrm{B}, \mathrm{M}, \mathrm{H} \\
\mathrm{M}, \mathrm{B}, \mathrm{H} \\
\mathrm{M}, \mathrm{B}, \mathrm{H}\end{array}$ & $\begin{array}{l}\text { B, M, H } \\
\text { B, M, H } \\
\text { M, B, H } \\
\text { M, B, H }\end{array}$ & $\begin{array}{l}\mathrm{B}, \mathrm{M}, \mathrm{H} \\
\mathrm{B}, \mathrm{M}, \mathrm{H} \\
\mathrm{M}, \mathrm{B}, \mathrm{H} \\
\mathrm{M}, \mathrm{B}, \mathrm{H}\end{array}$ \\
\hline $\begin{array}{l}\text { NES4 } \\
\text { Total energy consumption } \\
\text { Total energy expenditure } \\
\text { Electricity consumption } \\
\text { Electricity expenditure }\end{array}$ & $\begin{array}{l}\text { B, M, H } \\
\text { B, M, H } \\
\text { M, B, H } \\
\text { M, B, H }\end{array}$ & $\begin{array}{l}\mathrm{B}, \mathrm{M}, \mathrm{H} \\
\mathrm{B}, \mathrm{M}, \mathrm{H} \\
\mathrm{M}, \mathrm{B}, \mathrm{H} \\
\mathrm{M}, \mathrm{B}, \mathrm{H}\end{array}$ & $\begin{array}{l}\text { B, M, H } \\
\text { B, M, H } \\
\text { M, B, H } \\
\text { M, B, H }\end{array}$ \\
\hline $\begin{array}{l}\text { NES6 } \\
\text { Total energy consumption } \\
\text { Total energy expenditure } \\
\text { Electricity consumption } \\
\text { Electricity expenditure }\end{array}$ & $\begin{array}{l}\mathrm{B}, \mathrm{M}, \mathrm{H} \\
\mathrm{B}, \mathrm{M}, \mathrm{H} \\
\mathrm{M}, \mathrm{B}, \mathrm{H} \\
\mathrm{M}, \mathrm{B}, \mathrm{H}\end{array}$ & $\begin{array}{l}\mathrm{B}, \mathrm{M}, \mathrm{H} \\
\mathrm{B}, \mathrm{M}, \mathrm{H} \\
\mathrm{M}, \mathrm{B}, \mathrm{H} \\
\mathrm{M}, \mathrm{B}, \mathrm{H}\end{array}$ & $\begin{array}{l}\text { B, M, H } \\
\text { B, M, H } \\
\text { M, B, H } \\
\text { M, B, H }\end{array}$ \\
\hline
\end{tabular}

a Relative rankings, high to low; $M=$ majority, $B=$ black, $\mathrm{H}=$ Hispanic. 


\section{REFERENCES}

Anderson, J.L., et al., 1990, Minority Energy Assessment Model Personal Computer Software Documentation, Argonne National Laboratory Report ANL/ESD-TM-10, June.

Bozinovich, L.V., and D. Ungson, 1991, Least-Cost Utility Planning: An Annotated Bibliography, U.S. Department of Energy Report DOE/MI-49992-H1, July.

DOE (U.S. Department of Energy), 1990, The Annual Energy Outlook 1990, Energy Information Administration, DOE/EIA-0383(90).

DOE (U.S. Department of Energy), 1991, National Energy Strategy, First Edition, 1991/ 1992, Washington, D.C., Feb.

Phlips, L., 1983, Applied Consumption Analysis, North Holland Publishing Co., Amsterdam, The Netherlands.

Poyer, D.A., 1991, The Federal Energy Policy: An Example of Its Potential Impact on Energy Consumption and Expenditures in Minority and Poor Households, Argonne National Laboratory Report ANL/ESD/TM-48, Sept. 

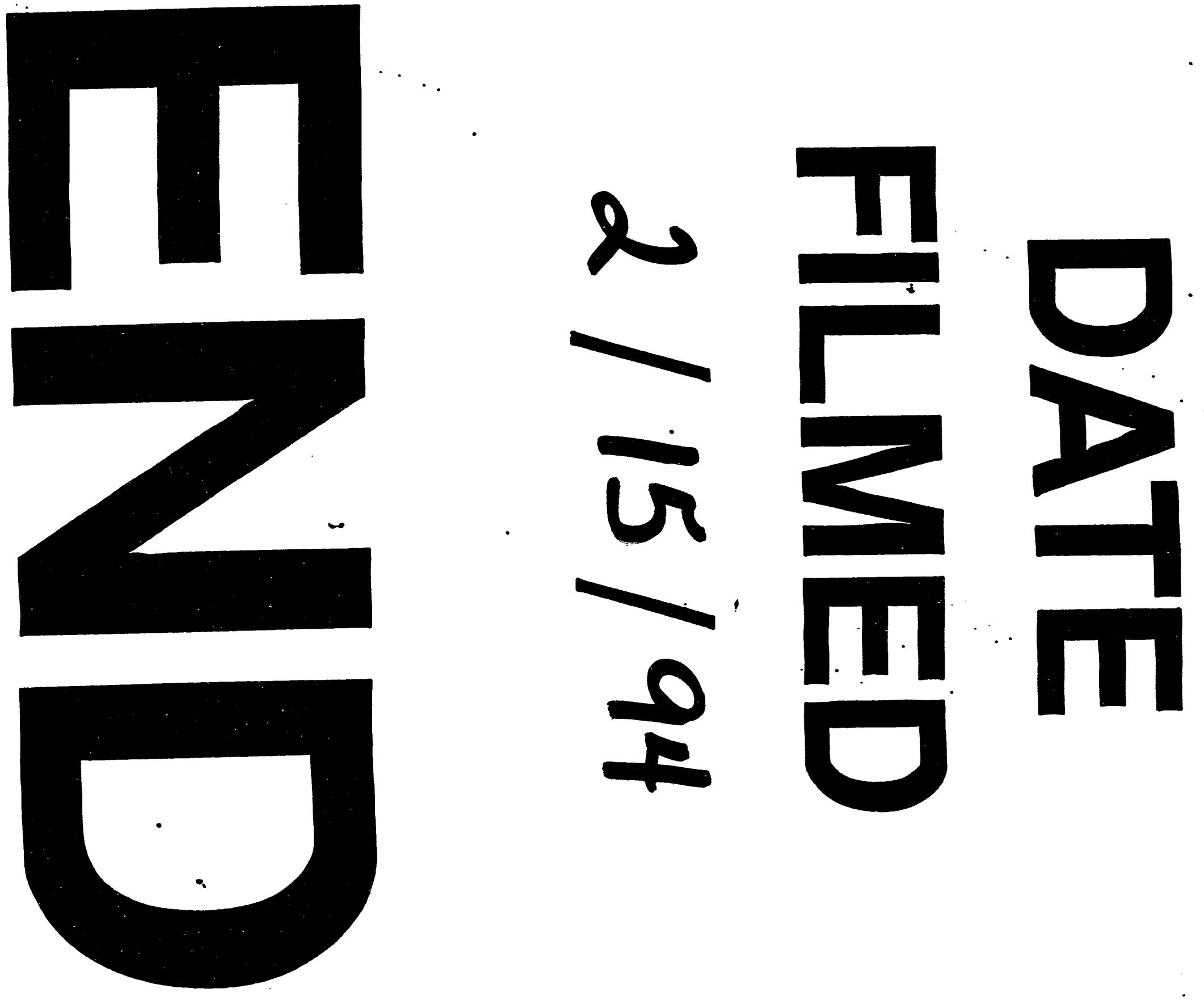


$$
-1
$$

$-$
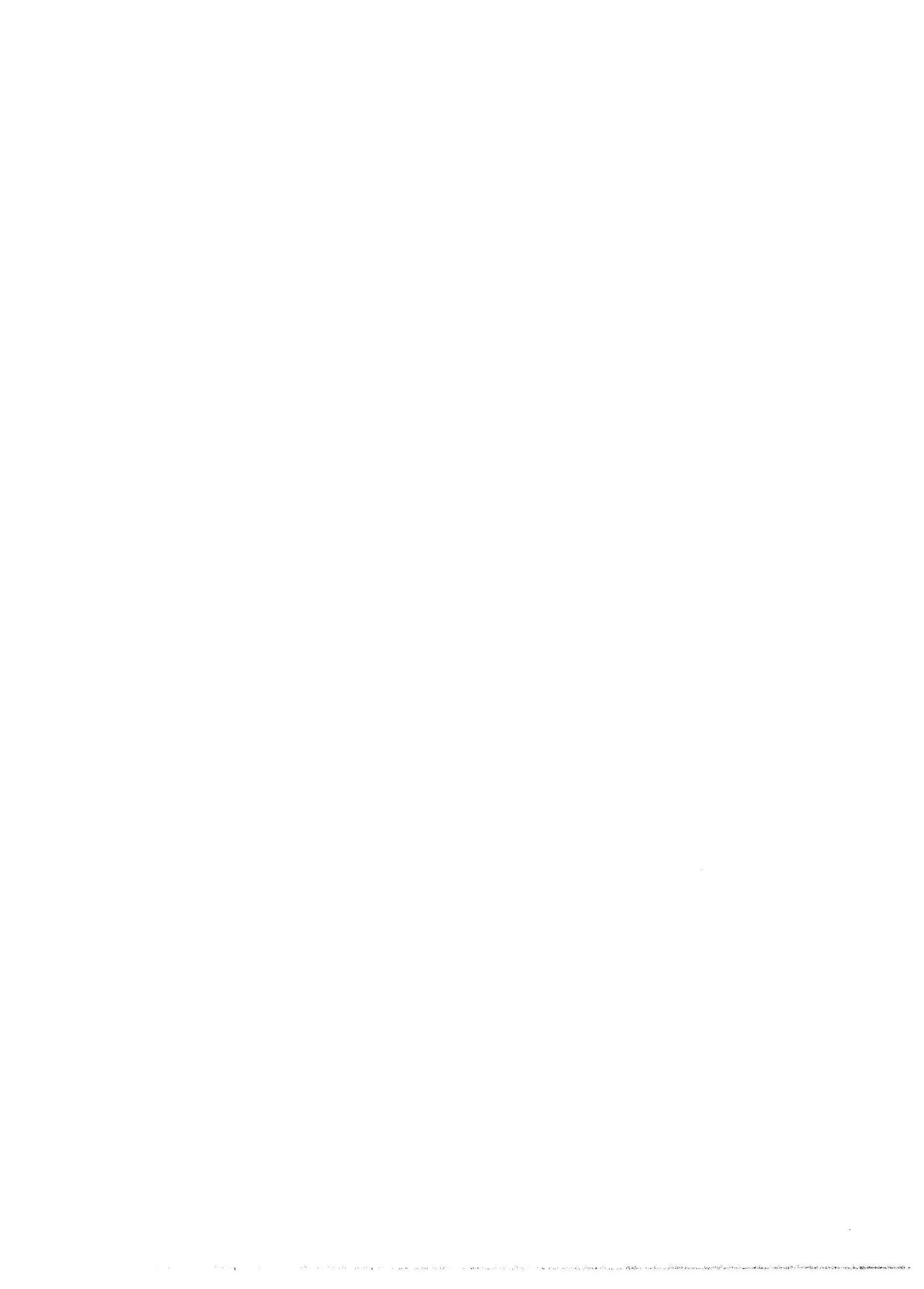